\title{
1 Infiltration and interrill erosion rates after a wildfire in western Montana, USA
}

3 Peter R. Robichaud ${ }^{\mathrm{a}^{*}}$, Joseph W. Wagenbrenner ${ }^{\mathrm{a} 1}$, Fredrick B. Pierson ${ }^{\mathrm{b}}$, Kenneth E. Spaeth ${ }^{\mathrm{c}}$,

4 Louise E. Ashmun ${ }^{\mathrm{a}}$, Corey A. Moffet ${ }^{\mathrm{b} 2}$

5

$6 \quad{ }^{a}$ U.S. Department of Agriculture, Forest Service, Rocky Mountain Research Station, 1221 South Main Street,

7 Moscow, ID 83843, USA. Email address: probichaud@fs.fed.us: leashmun.work@gmail.com

8 bU.S. Department of Agriculture, Agricultural Research Service, Northwest Watershed Research Center, 800 East

9 Park Boulevard, Plaza IV Suite 105, Boise, ID 83712, USA. Email address: Fred.Pierson@ars.usda.gov

10 'U.S. Department of Agriculture, Natural Resources Conservation Service, Central National Technology Support

11 Center, Fort Worth, TX 76115, USA. Email address: ken.spaeth@ftw.usda.gov

12 19resent address: School of Forest Resources and Environmental Science, Michigan Technological University, 1400

13 Townsend Drive, Houghton, MI 49931, USA. Email address: jwwagenb@mtu.edu

14 2Present address: The Samuel Roberts Noble Foundation, 2510 Sam Noble Parkway, Ardmore, OK 73401, USA.

15 Email address: camoffet@noble.org

16

*Corresponding author: Tel: +1 208883 2349; Fax: +1 208883 2318; e-mail address: probichaud@fs.fed.us 


\section{Abstract}

The 2000 Valley Complex wildfire burned in steep montane forests with ash cap soils in western Montana, USA. The effects of high soil burn severity on forest soil hydrologic function was examined using rainfall simulations $\left(100 \mathrm{~mm} \mathrm{~h}^{-1}\right.$ for $\left.1 \mathrm{~h}\right)$ on $0.5-\mathrm{m}^{2}$ plots. Infiltration rates, sediment yields and sediment concentrations were compared among three treatments: control (unburned and undisturbed); bare (unburned with all surface vegetation, litter, and duff removed prior to each simulation); and burned. Rainfall simulations were done immediately after the fire and repeated in 2001, 2002, and 2005. Soil moisture, water repellency, and understory canopy and ground cover were measured and related to infiltration rates and sediment yields. The unburned forest soil was water repellent at the mineral surface. This surface repellency was no longer detected after it was burned at high severity, but a post-fire water repellent soil layer was observed at 1-2 cm below the surface. The control plots had high ground cover (90\% overall), infiltration of 44-48 mm, and very low sediment concentrations (median values of $0.1-0.6 \mathrm{~g} \mathrm{~L}^{-1}$ ) and sediment yields $\left(6-54 \mathrm{~g} \mathrm{~m}^{-2}\right)$ for all years despite changes in soil moisture and strong water repellency. The bare and control plots had similar water repellency values, but the interrill erosion in the bare plots was high throughout the study $\left(624-1277 \mathrm{~g} \mathrm{~m}^{-2}\right)$. In the year of the fire, the burned sites had high rates of soil water repellency (88\%) and little ground cover (10\%). This resulted in low infiltration rates $(30 \mathrm{~mm})$, high sediment concentrations (median value $\left.21 \mathrm{~g} \mathrm{~L}^{-1}\right)$, and high sediment yields $\left(1157 \mathrm{~g} \mathrm{~m}^{-2}\right)$. By 2005, the fire-altered water repellency decreased in occurrence (48\%) and severity and the ground cover increased (42\%). This resulted in much greater infiltration $\left(84 \mathrm{~mm}\right.$ ), lower sediment concentration (median value $0.5 \mathrm{~g} \mathrm{~L}^{-1}$ ), and lower sediment yields $\left(15 \mathrm{~g} \mathrm{~m}^{-2}\right)$ on the burned plots. The importance of ground cover for preventing interrill erosion was demonstrated by the very low sediment yields on the control plots as compared to the bare and burned plots. The strength and occurrence of water repellency in both the unburned and burned sites decreased as soil moisture increased; however, strong soil water repellency was detected at the soil surface whenever unburned soils were dry. Fire-altered soil water repellency influenced the infiltration capacity and increased runoff rates immediately after 
45 the fire; however, the loss of protective ground cover was a more significant factor for the

46 increased sediment concentrations and sediment yields.

47 Keywords:

48 Ground cover, post-fire recovery, rainfall simulation, sediment yield, soil water repellency,

49 water drop penetration time

50 


\section{Introduction}

Post-fire increases in runoff, flooding, and erosion are generally attributed to the loss of vegetation and forest floor material which leaves the forest soil less protected and more vulnerable to the erosive effects of rainfall, overland flow, wind, and gravity. The direct effects of fire on forest soils, such as loss of organic matter and changes in soil water repellency, aggregate stability, and soil water retention, can change infiltration of water and runoff amounts and characteristics; thus contributing to post-fire erosion vulnerability as well (e.g., Bento-Gonçalves et al., 2012; Certini, 2005; DeBano et al., 1998; Inbar et al., 2014; Larsen et al., 2009; LeightonBoyce et al., 2007; Shakesby and Doerr, 2006). Understanding fire effects on infiltration is vital for the prediction of post-fire flooding and erosion responses.

Many factors control infiltration rates, and in forest environments vegetation is a dominant factor (Castillo et al., 1997; Cerdà, 1999; Cerdà and Doerr, 2005; Cerdà and Robichaud, 2009;

Faulkner, 1990). Vegetation increases infiltration rates by adding organic material to the soil, which improves soil structure and porosity, and by deepening the litter layer (Abrahams et al., 1995; Berndtsson and Larson 1987; Jiménez et al., 2006; Wilcox et al., 1988). The macropores developed by plant roots provide preferential flow paths (Beven and Germann, 2013) and also increase the water holding capacity of the soil. The litter and duff layers can further enhance infiltration by absorbing and storing water and allowing more time for infiltration into the soil (Brock and DeBano, 1982; Lowdermilk, 1930). Both the vegetation and the forest floor protect the mineral soil from direct impact of the rain drops and the subsequent destruction of the soil aggregates, compaction, slaking, particle segregation, and the filling and clogging of pores by the wash-in of fine material, all of which can form structural seals at the soil surface and reduce infiltration capacity (Assouline, 2004; Liu et al., 2011; Mataix-Solera et al., 2011; Woods and Balfour, 2010).

Fire-altered water repellency forms when surface vegetation, litter, and near-surface soil organic matter are burned and a fraction of the vaporized hydrocarbons condense on soil particles in the cooler layers beneath the surface (DeBano, 1981; Doerr et al., 2000). The degree and depth of 
the fire-altered soil water repellent layer varies with the degree of soil heating over small spatial scales (Huffman et al., 2001), resulting in preferential flow paths through less water repellent areas and the formation of uneven wetting fronts (Dekker and Ritsema, 1994, 1995; Ritsema and Dekker, 1994, 2000). Macro-pores such as root channels that remain after roots burn can also serve as pathways for water to infiltrate through water repellent layers (Burch et al., 1989; Doerr et al. 2006a; Meeuwig, 1971; Shakesby et al., 2000). Because of the reduced infiltration rates, overlying layers of ash and/or soil may saturate, and this could lead to lateral surface or nearsurface flow (Bodí et al., 2012; Doerr et al., 2006a; Ebel et al., 2012).

Soil water repellency has often served as a surrogate measurement of infiltration capacity in postfire assessments (DeBano, 1981; Parson et al., 2010; Robichaud et al., 2008). Although there is a clear association between fire-altered soil water repellency and enhanced post-fire hydrologic and erosion response, the effect of soil water repellency often has been oversimplified (Doerr et al., 2009a; Leighton-Boyce et al., 2007). The contribution of fire-altered soil water repellency on runoff and erosion is difficult to separate from other fire impacts such as loss of vegetation and forest floor material, decreased surface roughness, soil disaggregation, soil sealing, etc. (Doerr and Moody, 2004; Larson et al., 2009; Leighton-Boyce et al., 2007; Shakesby and Doerr, 2006). Soil water repellency is not only caused by fire, but is an inherent soil characteristic found in many types of soils with a range of textures, organic contents, vegetation, land uses, and locations (Doerr et al., 2006b; Jordán et al., 2009, 2013; Mataix-Solera et al., 2007). Long unburned forest soils with inherent soil water repellency at or near the soil surface have been observed worldwide in certain forest types (Doerr et al., 2006b; Doerr et al., 2009b). Although soil water repellency is classically associated with coarse-textured soils (Mataix-Solera et al., 2013; Moral García et al., 2005; Robichaud and Hungerford, 2000), the organic-rich surface layers of volcanic ash soils (andisols) have highly aggregated soil structure that retain water and are often water repellent when dry (Kawamoto et al., 2007). In addition, inherent soil water repellency in fine-textured soils more consistently decreases with depth and has a greater impact on infiltration than soil water repellency in coarser soils (Fox et al., 2007; Mataix-Solera et al., 
2013; Rodriguez-Alleres et al., 2007). In addition, inherent soil water repellency has been associated with vegetation that contains waxes, resins, or oils such as eucalyptus and pine trees and sagebrush and chaparral shrubs (DeBano, 1981; Lozano et al, 2013; Martínez-Zavala and Jordán-López, 2009; Mataix-Solera et al., 2007; Pierson et al., 2001).

Generally, both inherent and fire-altered soil water repellency is lost during long wet periods and is re-established upon drying, causing short-term or seasonal variations (de Jonge et al., 1999;

Dekker and Ritsema, 1996; Dekker et al., 2001; MacDonald and Huffman, 2004; Robichaud and Hungerford, 2000). The change in soil water repellency may occur over a range of soil moistures, or a "transition zone," such that both water repellent and wettable soils may exist within the transition zone but only water repellent conditions exist when soil moisture is below the lower boundary and only wettable conditions exist above the upper boundary (Dekker and Ritsema, 1994; Dekker et al., 2001; Regalado and Ritter, 2005).

The influence of forest floor material on infiltration rates into inherently water repellent soils is not easily determined. If the organic material that overlays the mineral soil helps maintain soil moisture above the threshold for wettability, it enhances infiltration (Feng et al., 2001; Lehty, 2001; Wang et al., 2000). However, short rainfall simulations may not capture this process. Leighton-Boyce et al. (2007) found that inherent soil water repellency in mature eucalyptus plantation sites persisted through a 30-min high intensity $\left(107 \mathrm{~mm} \mathrm{~h}^{-1}\right)$ rainfall simulation and that the majority of rainfall which did not become overland flow was stored within the litter layer rather than infiltrating into the soil.

Several others have used rainfall simulation to evaluate the impact of fires in coniferous forests (Table 1; see review by Vieira et al., 2015). However, the small plot rainfall simulations, such as those used in our study, may not accurately represent infiltration and erosion processes at larger scales. The short lengths of the rainfall simulation plots restrict erosion to rain splash and sheetwash (interrill) processes (Bryan, 2000; Huang et al., 2001). At larger scales, however, hillslope processes include differential flow patterns, detention and storage of runoff and sediment, and rill erosion. Generally, small plots have greater per-unit-area runoff rates than 
larger scales where the existence of preferential flow paths may create scattered "sink" areas across a hillside that allow water to infiltrate (Imeson et al., 1992; Nyman et al., 2010; Prosser and Williams, 1998; Stoof et al., 2012). Yet these studies can provide insight to fire effects especially when unburned plots are used for comparison (Table 1).

Given the large, and occasionally extreme, post-fire runoff events and the associated flooding and erosion, the need to understand and accurately predict post-fire hydrologic and geomorphic responses continues to drive research (Moody et al., 2013). We measured the immediate and short-term effects (5 years) of high severity wildfire on infiltration rates, interrill erosion rates, and other related variables. Specifically, the objectives of the study were to use small-plot rainfall simulations to compare infiltration rates, sediment concentrations, and sediment yields among three treatments - unburned with no recent disturbance (control), unburned with surface litter, duff, and vegetation removed (bare), and burned at high soil burn severity (burned). Soil water repellency, canopy cover and ground cover were also compared. Rainfall simulations and other measurements were done immediately after the fire and repeated in post-fire years one, two, and five to measure temporal affects.

\section{Materials and methods}

\subsection{Site description}

We measured the runoff and sediment concentrations from simulated rainfall on seven forested sites within the 144,000 ha burn perimeter of the 2000 Valley Complex Fire in the Bitterroot Valley, Montana (Fig. 1). About a third of this area burned at high soil burn severity (USDA Forest Service 2000), our study site was in the high soil burn severity portion of the burned area and adjacent unburned area. Three unburned sites (U5-U7) and four high soil burn severity sites (B1-B4) (approximately $3 \mathrm{~km}$ south) were selected based on similarity of slopes (37-50\%), elevations (1880-2050 m), aspects (200-285 degrees, with the exception of U5 with an aspect of 150 degrees), and road access. For all seven sites, the vegetation or pre-fire vegetation was sub-alpine fir (Abies lasiocarpa) and fool's huckleberry (Menziesia ferruginea). Soils were derived from volcanic ash underlain by weathered granite with a soil classification of 
sandy skeletal andic-dystrocryept (McBride, 2000; USDA Forest Service, 2000). The Daly Creek

snow telemetry site was used to compare precipitation during the study period to the 1981-2006 average annual precipitation of $636 \mathrm{~mm}$ (NRCS, 2007). About two-thirds of the annual precipitation occurs as snow.

\subsection{Plot preparation and measurements}

A total of 102 plots were installed across burned and unburned sites with 14 plots at each of the three unburned sites and 15 plots at each of the four burned sites. On seven unburned plots at each unburned site, the litter, duff, vegetation, and surface roots were removed before each simulation for each year of simulation, leaving a surface of exposed ("bare") mineral soil (Fig. 2). Longer roots, such as taproots, that extended below the surface were cut at the surface of the mineral soil. All of the overlying material that was removed from the bare plots in 2000 was dried and weighed and then saturated and weighed to determine the water storage capacity of the litter and duff layers from the unburned plots. The remaining unburned plots $(21$ plots - seven at each unburned site) were left undisturbed as controls.

Rainfall simulations were conducted on 0.75 by $0.75 \mathrm{~m}\left(0.5-\mathrm{m}^{2}\right)$ plots bounded by a 15 $\mathrm{cm}$ tall steel square frame. Each plot frame was inserted $5 \mathrm{~cm}$ into the ground leaving $10 \mathrm{~cm}$ extending above the ground surface. A covered tray at the downhill end of the frame captured runoff at the ground surface and routed the runoff into a pipe used for sampling. The interior edges of the plot were filled with a bentonite mixture to reduce the occurrence of preferential flow paths along the edges of the plot frames. The slope of each plot was measured using an Abney level on the sides of the plot frame. Plots were established and rainfall simulations conducted within a few weeks of fire containment, between 12 and 20 September 2000 (post fire year 0 [PF0]). The rainfall simulations were repeated on 14 plots (three control, three bare, and eight burned) shortly after snow melt, between 19 and 21 June 2001 (spring PF1) to evaluate the effects of higher soil moisture. Simulations repeated on all available plots between 7 and 10 August 2001 (PF1), 28 July and 5 August 2002 (PF2), and 28 July and 1 August 2005 (PF5). Some plot frames were damaged between annual measurements, leaving 20 control, 17 bare, and 
54 burned plots to be tested in PF5. We present the results from the spring PF1 simulations separately because of the smaller number of replicates, and compare the results from spring PF1 to the same-plot results from PF0 and summer PF1.

Prior to the first rainfall simulation in PF0, five soil samples from two depths $(0-5 \mathrm{~cm}$ and 5-10 cm) were obtained from each of the seven sites to determine soil bulk density (Blake and Hartge, 1986) and soil particle size distribution (Gee and Bauder, 1986). At each plot prior to every rainfall simulation, soil water repellency, understory canopy cover, ground cover, and soil moisture at a depth of $0-5 \mathrm{~cm}$ were measured. The soil water repellency was measured using the Water Drop Penetration Time (WDPT) test (DeBano, 1981) using eight drops on the mineral surface just outside of each plot frame. If any of the drops infiltrated within $5 \mathrm{~s}$, the drop was repeated at a depth of $1 \mathrm{~cm}$. This process was repeated at $1 \mathrm{~cm}$ depth increments until the WDPT time was greater than $5 \mathrm{~s}$ or a depth of $5 \mathrm{~cm}$ had been reached. For water drops that remained on the surface for more than $5 \mathrm{~s}$, the time until infiltration was used to classify the soil water repellency—slight (5-60 s), moderate (60-180 s), or severe (180 s or more). The percent of the drops that remained on the soil for more than $5 \mathrm{~s}$ at depths of 0 to $3 \mathrm{~cm}$ was calculated for each plot and termed “water repellency occurrence.”

Understory canopy cover and ground cover were estimated visually to the nearest percent within each $0.5-\mathrm{m}^{2}$ rainfall plot using a scaled quadrat (Dethier et al., 1993). The canopy cover of each understory species was estimated (Elzinga et al., 1998) and added for a total canopy cover which sometimes exceeded $100 \%$ because of overlapping foliage layers. Similarly, coverage of each category of ground cover (moss, lichen, litter, tree roots, and surface rock $<5 \mathrm{~mm}$ ) was estimated and then added to obtain the total plot ground cover. The proportion of bare soil was the difference between $100 \%$ and the sum of ground cover and basal plant cover. The canopy and 
ground cover measurements were forced to zero for the bare plots, and these were not included

210 in the statistical analysis.

\subsection{Rainfall simulation}

Rainfall simulations were used to measure in situ infiltration rates, and provide a mechanism for replicating the same rain storm over many plots (Peterson and Bubenzer, 1986). Rainfall was applied to each plot at a rate of $100 \mathrm{~mm} \mathrm{~h}^{-1}$ for $60 \mathrm{~min}$ using a modified Purdue-type rainfall simulator located $3 \mathrm{~m}$ above the center of the plot (Bertrand and Parr, 1961). The vee-jet nozzle provides energy of $275 \mathrm{Kj}_{\text {ha- }} \mathrm{mm}^{-1}$ at $3 \mathrm{~m}$ height with an average drop diameter of $3 \mathrm{~mm}$ at a terminal velocity of $8.8 \mathrm{~m} \mathrm{sec}^{-1}$ (Meyer and Harmon, 1979). Prior to each simulation, the rainfall was collected in a calibration pan covering the plot and measured with a graduated cylinder. The flow rate to the nozzles was adjusted so that the same per-unit-surface area rainfall rate was applied by repeating the calibration process if the slope-adjusted rainfall rate differed from the target rate by more than 5\%. The time from the start of rainfall until the start of runoff was recorded. Timed runoff samples were collected for 45-60 s of each minute during the first $30 \mathrm{~min}$ of the simulation and for 75-90 s of every $2 \mathrm{~min}$ for the last $30 \mathrm{~min}$ of the simulation. If necessary, sample times were adjusted so that samples would fit in a 1-L bottle. Any sediment remaining in the sample tray was collected after the simulation was complete.

Sediment-laden water samples were weighed in the lab, dried, and re-weighed to obtain the sample runoff volume $(\mathrm{mm})$ and the sediment concentration $\left(\mathrm{g} \mathrm{L}^{-1}\right)$. The weight of any residual sediment in the tray was also dried and included in the total sediment yield $\left(\mathrm{g} \mathrm{m}^{-2}\right)$ for each rainfall simulation.

After each simulation, the wetting front into the soil profile was measured. A trench was excavated adjacent to each plot to expose a $20-\mathrm{cm}$ deep by $50-\mathrm{cm}$ wide cut face. The presence of wet or dry soil was recorded for each 2 -cm square ( 25 squares across and 10 squares deep) on the exposed face. The total wetted area was the percentage of 2-cm squares (250 squares total) that were designated as wet. 


\subsection{Calculations and statistical analysis}

For each simulation, the total rainfall applied was calculated from the calibration sample volume and the duration of the simulation. The total runoff $(\mathrm{mm})$ for each simulation was calculated from the runoff rates $\left(\mathrm{mm} \mathrm{h}^{-1}\right)$ and the sample duration, and extrapolated over the time between samples. Infiltration rates $\left(\mathrm{mm} \mathrm{h}^{-1}\right)$ were the difference between rainfall and runoff per unit time. The total sediment yield $\left(\mathrm{g} \mathrm{m}^{-2}\right)$ was similarly extrapolated from the timed samples and the duration of the simulation, and included any sediment from the tray.

The results were statistically analyzed using an unbalanced split plot design in several different linear mixed-effects models (SAS Institute, 2012). The whole plot treatment (by site) was either unburned or burned. The split plot treatment (by plot) for the unburned sites was control or bare. Repeated measures analyses were conducted for soil moisture, runoff, and total infiltration using linear mixed-effects models (Littell et al., 2006), while canopy cover, ground cover, occurrence of soil water repellency, and sediment yield were analyzed using generalized linear models (Littell et al., 2006). In each case, treatment and number of years after fire were fixed factors, the spacing between measurements was the number of months after the fire, and plot and site were random variables. The significance of multiple comparisons among treatments was tested using the differences among least-squares means with a Tukey-Kramer adjustment (Ott and Longnecker, 2001). The canopy and ground cover data were transformed using the square-root function to increase the normality of the residual errors (Ott and Longnecker, 2001), and the transformed data were modeled using the Poisson distribution. The ground cover and canopy cover were not independent of the bare treatment, so univariate linear regressions were used to evaluate the effect of ground cover and canopy cover on runoff and sediment yields and the cover responses for the bare plots were not directly compared to the control or burned plots. The occurrence of water repellency was modeled as a binomial distribution using the ratio of the number of water drops that indicated water repellency divided by the total number of water drops tested. The sediment yield was modeled using the lognormal distribution. The soil moisture was also tested as a covariate for total infiltration and sediment yield and retained in the statistical 
model if it was significant. The particle size distributions of burned and the unburned surface soil were compared using $T$ tests on the $\mathrm{D}_{15.9}, \mathrm{D}_{50}$, and $\mathrm{D}_{84.1}$ values of the composite surface soil samples taken the first year (2000) of the study. A significance level of 0.05 was used for all statistical tests.

\section{Results}

\subsection{Site and plot characteristics}

\subsubsection{Fire effects on soil}

There was little or no difference in soil bulk density by treatment (average BD $=0.46 \mathrm{~g} \mathrm{~cm}^{-}$ ${ }^{3}$ for burned and $0.44 \mathrm{~g} \mathrm{~cm}^{-3}$ for unburned) or by depth (average $\mathrm{BD}=0.45 \mathrm{~g} \mathrm{~cm}^{-3}$ for both $0-5$ $\mathrm{cm}$ and 5-10 $\mathrm{cm}$ depths). However, the particle size distribution in the burned soil was significantly finer than the size distribution in the unburned soil, with the burned soils having smaller diameter particles represented by the $\mathrm{D}_{15.9}, \mathrm{D}_{50}$, and $\mathrm{D}_{84.1}$ fractions (Fig. 3).

\subsubsection{Soil moisture}

The annual precipitation in the four simulation years (PF0-PF2 and PF5) was less than the 25-yr mean $(636 \mathrm{~mm})$, with the lowest annual precipitation of the study occurring in PF0 (82\% of the 25-yr mean). July and August of PF0 were much drier than normal, with precipitation just $34 \%$ of the $25-y r$ mean for the same 2 -mo period $(78 \mathrm{~mm})$. This small amount of rainfall resulted in low soil moisture values at the end of summer when the initial rain simulations were done. In PF0, the control plots had 18\% soil moisture, which was not significantly different from the bare or the burned plots (Table 2).

Precipitation in July and August of PF1 and PF2 was greater than normal, with precipitation being $147 \%$ and $127 \%$ respectively of the 25 -yr mean for the same period. In PF1 and PF2, the average soil moisture on the unburned control plots (33\% and 44\%, respectively) and the bare plots (36\% and 44\%, respectively) was greater than in PF0, but the soil moisture on the burned plots remained consistently low (15 and 17\%, respectively) and not significantly different from PF0 (Table 2). 
The period from October 2004 to April 2005 was drier than the 25-yr mean but May 2005 was wetter than average and the mean precipitation for June 2005 was nearly double the $25-y r$ mean. This relatively wet period was followed by just $2.5 \mathrm{~mm}$ of precipitation in Julysignificantly less than the 25-yr mean value of $39 \mathrm{~mm}$ (Table 2). The PF5 rain simulations were done at the end of July 2005 and soil moistures on the control and bare plots (24\% and 15\%, respectively) were low and comparable to those measured immediately after the fire in PF0 (Table 2). Mean soil moisture on the burned plots was only $3 \%$, which was the lowest value measured during the study, but not significantly different from mean values on the unburned plots in PF0 or the bare plots in PF5 (Table 2).

\subsubsection{Understory Canopy and Ground Cover}

There was no difference in understory canopy cover in the control plots between PF0 and PF1 (mean of 27\%), but the canopy cover increased to 42\% in PF2 and increased again to 59\% in PF5. The burned plots had negligible canopy cover following the fire in PF0, but vegetation increased on these plots throughout the study resulting in canopy cover values of $7 \%$ in PF1, 33\% in PF2, and 45\% in PF5 (Table 2). In PF2, the influx of fireweed (Chamerion angustifolium L. Holub.) on the burned plots accounted for much of the increase in mean canopy cover. By PF5, the fireweed had subsided, but increases in Scouler's willow (Salix scouleriana Barratt ex Hook.) and thin leaf huckleberry (Vaccinium membranaceum Dougl. ex Torr.) increased canopy cover. These changes in vegetation resulted in no significant differences in mean canopy cover between the control and burned plots in either PF2 or PF5 (Table 2).

The ground cover on the control plots remained consistently high for the five years of the study with an overall mean of $90 \%$ (Table 2). The litter and understory vegetation was removed from the bare plots, and the water held by the dried litter, duff, and fine roots removed was equivalent to $17 \mathrm{~mm}$. The ground cover on the burned plots was significantly less than the controls for the first 3 years of the study-10, 6, and 17\% for PF0, PF1, and PF2, respectively. 
313 Although the PF5 mean ground cover value on the burned plots (42\%) was less than half of the 314 value for the control plots, the wide variation in measured values resulted in a lack of statistical 315 difference between the burned and control plots (Table 2).

316 3.1.4 Water repellency

In PF0, the soil was relatively dry (17-18\%) following the period of low rainfall, and the occurrence of moderate to severe soil water repellency at depths to $3 \mathrm{~cm}$ was high $(81 \%$ overall average) and showed no significant difference among treatments (Table 2). However, the soil water repellency was concentrated at the mineral soil surface in the unburned (control and bare) plots, and was concentrated 1 to $2 \mathrm{~cm}$ below the surface on the burned plots (Fig. 4).

In PF1, soil moisture had increased in the unburned plots (33-36\%) and the mean soil water repellency occurrence values were significantly lower for the control (39\%) and bare (38\%) plots as compared to the burned plots (79\%) (Table 2). The occurrence of soil water repellency in the control and bare plots remained concentrated on the soil surface, but the “severe” water repellency measurements that predominated in PF0 had nearly disappeared and most of the soil water repellency measurements were "slight" and "moderate" (Fig. 4). In the burned plots, soil water repellency occurrence was similar to PF0 (Table 2), but it was concentrated at $0-1 \mathrm{~cm}$ depth and the proportion of "severe" water repellency measurements decreased with a concomitant increase in "slight” water repellency measurements (Fig. 4).

In PF2, the soil moisture in the unburned plots remained high (44\%). The mean soil water repellency occurrence in the control plots was 51\% and the bare and burned plots did not differ statistically from this value (Table 2 ). However, the $48 \%$ mean soil water repellency occurrence in the burned plots was significantly less than in PF1, and the water repellency appeared evenly dispersed from 0-3 cm depth (Fig. 4). By PF5, the control and bare plots had low soil moisture and high occurrences of soil water repellency at the surface of the mineral soil with no 
significant differences between years PF0 and PF5 in either variable (Table 2; Fig. 4). In contrast, despite the very low soil moisture, in PF5 the burned plots had only $45 \%$ occurrence of soil water repellency which was predominately "slight” and concentrated at the soil surface (Table 2; Fig. 4).

When substituted for measurement periods, soil moisture was a significant covariate for the occurrence of water repellency, and in this analysis, the treatment had no significant effect. This suggests that high soil moisture content reduced the occurrence of both inherent and firealtered soil water repellency.

\subsection{Rainfall simulation}

\subsubsection{Infiltration}

In PF0 the mean start of runoff on the control plots was 1.4 min with the mean infiltration rate decreasing sharply for the next $6 \mathrm{~min}$, and then decreasing very gradually throughout the remainder of the simulation (Fig. 5). The bare and the burned plots followed the same pattern, but the mean infiltration rates decreased more rapidly and leveled off at lower values (Fig. 5).

The mean total infiltration was $44 \mathrm{~mm}$ in the control plots as compared to the significantly smaller mean total infiltration in the burned plots of $31 \mathrm{~mm}$, and even smaller 19 $\mathrm{mm}$ on the bare plots. Although the magnitudes of the total infiltration varied and the differences among the treatments were not always significant, the mean infiltration values were greatest in the control plots, followed by the burned plots, and least in the bare plots through PF2 (Table 2). During the same time period the mean wetted area profile values, which are an indication of the total infiltration, were fairly similar among the three treatments but differed by year with values ranging from $24-35 \%$ in PF0, 86-91\% in PF1, and 72-76\% in PF2 (Fig. 6).

In PF5, there was no difference between the mean total infiltration on the control and bare plots (47 and $41 \mathrm{~mm}$, respectively), and these values were not significantly different from the PF0-PF2 results on the controls or the PF1-PF2 infiltration values on the bare plots (Table 2). However, the mean total infiltration on the burned plots increased to $84 \mathrm{~mm}$, and this was more 
than double the values measured in the first 3 years of the study and the largest total infiltration measured in the study (Table 2). The mean wetted area of mineral soil for the burned plots in PF5 (96\%) was also the largest value measured in the study (Fig. 6).

\subsubsection{Sediment}

Sediment concentrations in the runoff generally peaked early in the simulation and then decreased (Fig. 7). The magnitude of the peak concentration, the rate of decrease in sediment concentration, and the amount of runoff determined the total sediment yield from the plots. In PF0 the mean peak sediment concentration in the control plots was $6.7 \mathrm{~g} \mathrm{~L}^{-1}$ (Fig. 7). In the control plots the sediment concentration quickly receded to a value near zero with the median value being $0.6 \mathrm{~g} \mathrm{~L}^{-1}$ of runoff (Fig. 7). The sediment concentration results in the control plots were very similar among the four years (Fig. 7).

The sediment concentrations $\left(\mathrm{g} \mathrm{L}^{-1}\right)$ from the bare plots also peaked rapidly in the first 15 min of the simulation, but the magnitudes were much greater than in the control plots. The peak concentrations from the bare plots in PF0 and PF5 were about five times greater than the controls (36 and $38 \mathrm{~g} \mathrm{~L}^{-1}$, respectively), while the peaks in PF1 and PF2 were about two to three times greater than the controls (Fig. 7). In PF0-PF2 the mean sediment concentration in the bare plots quickly receded to about $10 \mathrm{~g} \mathrm{~L}^{-1}$ for the last $50 \mathrm{~min}$ of the simulation. The concentration from the bare plots in PF5 also receded quickly, but the final concentration was greater than in PF0PF2 (Fig. 7).

In PF0-PF1 the peak sediment concentration in the burned was about five times greater than the controls (38 and $35 \mathrm{~g} \mathrm{~L}^{-1}$, respectively) (Fig. 7). The rate of decrease in sediment concentration from the peak was also less and the mean sediment concentration in these two years never fell below $15 \mathrm{~g} \mathrm{~L}^{-1}$ (Fig. 7). The peak and final sediment concentrations from the burned plots were much lower in PF2 than in the same plots in PF0-PF1, but the values were still greater than the control plots. In PF5 the mean sediment concentration response in the burned plots closely resembled the response in the control plots (Fig. 7). 

from the plots. In PF0-PF5, the mean runoff from the control plots was similar and mean sediment yields were very small ( 7 to $54 \mathrm{~g} \mathrm{~m}^{-2}$; Table 2). In PF0 and PF1, the mean sediment yields on the bare plots (849 and $677 \mathrm{~g} \mathrm{~m}^{-2}$, respectively) and burned plots (1157 and $1099 \mathrm{~g} \mathrm{~m}^{-2}$, respectively) were not significantly different from each other and both were much greater than on the control plots (Table 2). In PF2, the burned plots had a lower mean sediment yield (391 $\left.\mathrm{g} \mathrm{m}^{-2}\right)$ than the bare plots $\left(624 \mathrm{~g} \mathrm{~m}^{-2}\right)$, but both the burned and bare plots still produced nearly two orders of magnitude more sediment than the control plots (Table 2). There was no significant change in the mean sediment yield from the bare plots in PF5 (1277 $\left.\mathrm{g} \mathrm{m}^{-2}\right)$ as compared to earlier simulations, and this value was still about 20 times greater than the sediment yield from the controls (Table 2). In PF5 the sediment yield in the burned plots was only $15 \mathrm{~g} \mathrm{~m}^{-2}$, and this was much lower than the values in PF0-2 but not significantly different from the mean value of $54 \mathrm{~g}$ $\mathrm{m}^{-2}$ produced in the control plots (Table 2).

\subsection{Spring PF1}

Precipitation in April and May of PF1 was less than normal, but when combined with melting snow it was enough to increase the soil moisture in the control plots to $74 \%$ (Table 3 ). The soil moisture of $21 \%$ in the burned plots was significantly lower than in the control plots but this value was still greater than the moisture in the burned plots in any of the summer simulations. The soil moisture value of $52 \%$ in the bare plots was not significantly different from the other two treatments. Mean occurrences of soil water repellency decreased significantly from their high values in PF0 to 4\%, 21\%, and 36\% for the control, bare, and burned plots, respectively (Table 3). The only seasonal differences in infiltration, runoff, or sediment yields were on the control plots where the mean infiltration value was greater in spring PF1 than the value on the same subset of plots in the summer PF1 (Table 3).

\section{Discussion}

\subsection{Fire effects on infiltration}


This study adds to the growing evidence that the effects of wildfire on water infiltration into soil are complex and involve several soil and hydrologic characteristics that vary within the spatial extent of the fire and across a temporal scale that extends many years after the fire. The measurements over the five years of this study allowed us to quantify the longer-term variability of post-wildfire infiltration in the ash cap soils that are characteristic of the forests of northern Montana and Idaho. In addition, both the seasonal and annual temporal variation in infiltration were associated with changes in soil water repellency.

The inherent surface soil water repellency, a common characteristic of ash cap soils (Kawamoto et al., 2007), was not detected in areas burned at high severity after the wildfire. A new, fire-altered water repellent soil layer was observed 1-2 cm below the surface (Fig. 4, Burned, PF0). Laboratory studies have shown that soil water repellency can be destroyed at high temperatures (DeBano, 1981; Robichaud and Hungerford, 2000), and it is possible that the surface water repellency was destroyed by heat and a new water repellent layer was created at the 1-2 cm depth. Translocation of soil water repellency from the surface to below the surface has also been demonstrated in areas burned by wildfire (e.g., Doerr et al., 2006a), and this is a more likely explanation for our results.

Both inherent and fire-altered soil water repellency were sensitive to soil moisture (Fig. 8). The occurrence of water repellency in the controls was similar under dry soil conditions (Table 2) whereas in Spring PF1 when the mean soil moisture was 74\%, no inherent soil water repellency was detected (Fig. 8; Table 3). This result is consistent with findings of several previous studies that relate soil moisture to soil wettability (e.g., Bodí et al., 2013; Czachor et al., 2010; MacDonald and Huffman, 2004; Vogelmann et al., 2013; Zehe et al., 2007).

In contrast to the inherent soil water repellency, the fire-altered water repellency was essentially gone in PF5 (Fig. 4). Some water repellency was observed at the surface of the burned soil in PF5, and we attribute this to the very low soil moisture (Doerr et al., 2006b). Recovery of inherent water repellency after a wildfire is not well established. Jordán et al. (2009) reported that soil water repellency comparable to the unburned condition was practically re-established 
just 18 months after an intense experimental fire in a Mediterranean heathland. However, Doerr et al. (2006a) found that inherent surface water repellency destroyed by a high severity fire did not show signs of recovering after two years. In the Mediterranean ecosystem of Israel, soil in the burned areas remained wettable two decades after forest fires had destroyed the inherent soil water repellency (Tessler et al., 2013). The re-establishment of inherent soil water repellency after wildfires is highly dependent on restoration of organic matter within the soil, which gradually returns as decayed organic matter builds up and micro-organisms and fine roots are reestablished in the upper horizon of the soil-a process that may take decades (Tessler et al., 2013).

Several factors can affect the infiltration rate from rainfall simulations, including: the amount of interception and storage by understory canopy and ground cover; flow through macropores such as root holes; soil sealing by rain drop impact or mobilization of fine soil, ash, or organic particles into surface pores; or presence of a water repellent layer. Infiltration values on the control plots remained constant and high $(44-48 \mathrm{~mm})$ throughout this study despite variations in soil moisture and water repellency, likely due to the high porosity of the ash-cap soil (Shoji et al., 1993). The runoff ratios in our control plots are consistent with other studies in unburned pine forests where high rainfall intensities were simulated (Table 1).

Despite the relatively uniform runoff ratios through our study, the wetted areas from the postsimulation excavations on the control plots showed very little rainfall had infiltrated into the dry, water repellent soil in PF0 and PF5 (Fig. 6). Given that forest floor material in pine forests absorbs and holds large amounts of rainfall (Neris et al., 2013), much of the simulated rainfall attributed to infiltration on the control plots likely was stored in the litter and duff that covered the plots (Leighton-Boyce et al., 2007). The water stored in the litter, duff, and fine roots removed from the bare plots accounted for about $68 \%$ of the difference in infiltration between the control and the bare plots in PF0. We attribute the remaining 32\% to lower infiltration capacity resulting from soil sealing and redistribution of fine soil particles in the bare plots. The lower 
infiltration volumes in the bare plots than the controls in PF1-PF5 can be accounted for by mostly the loss of litter storage and some soil sealing.

The difference in infiltration between the burned and control plots in PF0-2 (7-13 mm) can be accounted for by the loss of litter storage in the burned plots. The burned plots also had some additional moisture storage capacity in the soil above the water repellent layer at $1 \mathrm{~cm}$. We suspect that soil sealing was also a factor given the lack of soil structure and finer soil particle size distribution in the burned soil (Fig. 3).

The ground cover on the burned plots was less than half the value on the control plots, so litter storage does not explain the higher infiltration rate in the burned plots in PF5. Although we did not evaluate all of the soil in the plots, the cut faces we did expose showed no signs of macropore flow. We did not measure soil sealing directly but because of the much greater amount of litter in the control plots than in the burned plots in PF5, soil sealing either was not a factor. We therefore ascribe the greater infiltration rates in the burned plots to the very low occurrence and severity of the fire-altered soil water repellency as compared to the prevalent and severe inherent water repellency in the control and bare plots (Table 2).

These findings suggest that modeling infiltration rates in water repellent soils should account for: 1) the dynamic soil water repellency as a function of soil moisture; 2) the changes in severity of fire-altered soil water repellency in the first few years after wildfire; and 3) when present in unburned conditions, the longer term recovery of inherent water repellency in burned soils.

\subsection{Fire effects on interrill erosion}

The combination of treatments in our study provides some mechanistic understanding of rain splash erosion, specifically with regards to the protection of the soil surface provided by understory canopy and ground cover (Table 2). As a result, the control plots had consistently low sediment concentrations and sediment yields similar to those measured in other studies (Table 1). The main factor affecting of sediment production within the narrow range observed in the control plots was the amount of runoff produced under the various soil moisture and soil water 
repellency conditions. In the case of the control plots, the soil water repellency was both a direct and indirect control on sediment production, as the water repellency allowed greater amount of rain splash erosion (Ahn et al., 2013) and it reduced the infiltration rates, leading to more overland flow for additional detachment and transport of sediment.

In contrast, the mineral soil in the bare plots was exposed to the full impact of the simulated rainfall. The small variation in sediment yields in the bare plots was related to the amount of disturbance required to remove the litter and vegetation, which was highest in PF0 and PF5. These periods also had the highest occurrence of soil water repellency in the bare plots because of the low soil moisture conditions, but the sediment yields from the bare plots during the other simulations did not correlate to soil water repellency (Table 2).

The $1757 \mathrm{~g} \mathrm{~m}^{-2}$ measured in the burned plots in PF0 was higher than the values from other rainfall simulation studies in burned pine forests (17-1040 $\mathrm{g} \mathrm{m}^{-2}$; Table 1). We attribute the greater sediment yield to the higher rainfall intensity in the current study than the previous simulations. The sediment yields in our burned plots decreased as the ground cover increased (Table 2), and the ground cover was the best predictor of sediment yields in the burned plots (Benavides-Solorio and MacDonald, 2001; Johansen et al., 2001; Robichaud et al., 2013a). Consequently, post-fire prediction models should account for: 1) the expected rainfall intensity at the location of interest; 2) the short term (minutes) changes in interrill erosion rates within a rain event as measured in our simulations (Fig. 5); and 3) the long term (1-5 years) post-fire recovery of protective ground cover, which may vary with climate and soil conditions (Robichaud et al., 2013b).

\section{Conclusions}

This post-wildfire infiltration and erosion study took place in a steep montane conifer forest with inherently water repellent ash cap soils. Small-plot rainfall simulations $\left(100 \mathrm{~mm} \mathrm{~h}^{-1}\right.$ for $60 \mathrm{~min}$ ) were applied to compare infiltration and sediment yields from interrill erosion among unburned plots that were untreated (control) or had surface vegetation, litter, and duff removed prior to each simulation (bare), and plots burned at high severity (burned). Rainfall simulations 
and associated measurements were done immediately after the wildfire in 2000 (PF0). A sample of the simulations were repeated under high soil moisture conditions in spring 2001. Simulations were repeated on all available plots in the summers of 2001 (PF1), 2002 (PF2), and 2005 (PF5) making this one of very few post-fire studies to extend for 5 years.

The unburned soil was inherently water repellent at its surface and the burned soil had no surface water repellency but had a layer of water repellent soil at $1-2 \mathrm{~cm}$ deep. Both the inherent and fire-altered soil water repellency were stronger and more extensive under low soil moisture conditions. The occurrence and severity of the fire-altered soil water repellency decreased over time and by PF5 the fire-altered soil water repellency was significantly reduced in severity and occurrence. In contrast, there was no change over time in the inherent soil water repellency in the control and bare plots - it was equally pervasive in PF0 and PF5 (93-99\%).

Despite the prevalent and severe water repellency in the control plots, the infiltration in the controls was $44-48 \mathrm{~mm}$ during the summer simulations. The control plots had extensive ground cover of litter and duff as well as understory canopy cover from low shrubs, forbs, and grasses which protected the mineral soil from rain splash erosion. The runoff collected from the control plots had consistently low sediment concentrations which resulted in low sediment yields. Infiltration on the bare plots, as determined by the runoff mass balance and by observing the wetness of the post-simulation excavated soil, was always less than the controls, but the differences were not always significant. Without any protective ground or canopy cover, the sediment concentrations in the runoff from the bare plots were always much greater than the controls, and the higher sediment concentrations and runoff amounts led to significantly greater sediment yields.

The infiltration and sediment responses on the burned plots changed over time reflecting some post-fire recovery over the five year study. In PF0 and PF1, the burned plots had high occurrence of soil water repellency, low infiltration, and little ground or canopy cover which resulted in very high sediment concentrations in the runoff and sediment yields. In PF2, the soil water repellency decreased, but this did not affect the infiltration rates. The increase in ground 
and canopy cover in PF2 led to a mean sediment yield that was about a third of the amount measured in PF1. In PF5 the burned plots had significantly less water repellency and significantly greater ground and canopy cover and infiltration, and the result was very low sediment concentrations and a mean sediment yield $\left(15 \mathrm{~g} \mathrm{~m}^{-2}\right)$ that was comparable to the yields from the controls.

Our results indicate that both ground cover and soil water repellency affect the infiltration capacity in ash cap soils. Comparisons between the bare and control plots showed that removal of the surface cover, with its requisite water storage capacity, explained most of the decrease in infiltration in the bare plots, and we attribute the remainder to sealing of the exposed soil. In the burned plots, the fire-altered water repellency changed during the five years of post-fire recovery, and the infiltration volumes decreased as the repellency diminished.

The interrill erosion was consistently high in the bare plots, and reflects their relatively consistent surface conditions. In contrast, the erosion in the burned plots decreased each year and was comparable to the interrill erosion in the controls in the fifth post-fire year. The higher initial rates can be attributed to lack of cover and subsequently high rain splash erosion rates, relatively low infiltration, and high availability of mobile soil particles. The interrill erosion in the burned plots diminished over time as the fire altered water repellency decreased, allowing greater infiltration, and as the surface cover recovered.

\section{Acknowledgements}

Funding for this project was provided in part by the U.S. Department of Agriculture (USDA), Forest Service and Department of Interior Joint Fire Science Program and the Rocky Mountain Research Station (USDA, Forest Service) and Northwest Watershed Research Center (USDA, Agricultural Research Service). The dedicated field crews from the Rocky Mountain Research Station and Northwest Watershed Research Center were essential to the success of this research. We thank the Bitterroot National Forest for their administrative and logistical support. 


\section{References}

Abrahams, A.D., Parsons, A.J., Wainwright, J., 1995. Effects of vegetation change on interrill runoff and erosion, Walnut Gulch, southern Arizona. Geomorphology 13, 37-48.

Ahn, S., Doerr, S.H., Douglas, P., Bryant, R., Hamlett, C.A.E., McHale, G., Newton, M.I., Shirtcliffe, N.J., 2013. Effects of hydrophobicity on splash erosion of model soil particles by a single water drop impact, Earth Surf. Process. Landf. 38(11), 1225-1233.

Assouline, S., 2004. Rainfall-induced soil surface sealing: A critical review of observations, conceptual models, and solutions. Vadose Zone J. 3, 570-591.

Benavides-Solorio, J., MacDonald, L.H., 2001. Post-fire runoff and erosion from simulated rainfall on small plots, Colorado Front Range. Hydrol. Processes 15, 2931-2952.

Bento-Gonçalves, A., Vieira, Al, Úbeda, X., Martin, D., 2012. Fire and soils: Key concepts and recent advances. Geoderma 191, 3-13.

Berndtsson, R., Larson, M., 1987. Spatial variability of infiltration in a semiarid environment. J. Hydrology 90, 117-133.

Bertrand, A.R., Parr, J.F., 1961. Design and operation of the Purdue sprinkling infiltrometer. Research Bulletin No. 723. U.S. Department of Agriculture, Purdue University Agricultural Experiment Station, Lafayette, Indiana, USA.

Beven, K.F., Germann, P., 2013. Macropores and water flow in soils revisited. Water Resources Res. 49(6), 3071-3092.

Blake, G.R., Hartge, K.H. 1986. Bulk Density. In: Klute, A. (ed.), Methods of Soil Analysis: Part 1, American Society of Agronomy, Madison, Wisconsin, USA, pp. 363-382.

Bodí, M.B., Doerr, S.H., Cerdà, A., Mataix-Solera, J., 2012. Hydrological effects of a layer of vegetation ash on underlying wettable and water repellent soil. Geoderma 191, 14-23. 
Bodí, M.B., Muñoz-Santa, I., Armero, C., Doerr, S.H., Mataix-Solera, J., Cerdà, A., 2013. Spatial and temporal variations of water repellency and probability of its occurrence in calcareous Mediterranean rangeland soils affected by fires. Catena 108, 14-25.

Brock, J.H., DeBano, L.F., 1982. Runoff and sedimentation potentials influenced by litter and slope on a chaparral community in central Arizona. In: Conrad, C.E., Oechel, W.C.

(Technical Coordinators), Proceedings of the symposium on Dynamics and Management of Mediterranean-Type Ecosystems, General Technical Report PSW-58. U.S. Department of Agriculture, Forest Service, Pacific Southwest Forest and Range Experiment Station, Berkley, California, USA, pp. 372-377.

Bryan, R.B., 2000. Soil erodibility and processes of water erosion on hillslope. Geomorphology 32, 385-415.

Burch, G.J., Moore, I.D., Burns, J., 1989. Soil hydrophobic effects on infiltration and catchment runoff. Hydrol. Processes 3, 211-222.

Castillo, V., Martínez-Mena, M., Albaladejo, J., 1997. Runoff and soil loss response to vegetation removal in a semiarid environment, Soil Science Soc. Amer. J. 61, 1116-1121.

Cerdà, A., 1999. Parent material and vegetation affect soil erosion in eastern Spain. Soil Science Soc. Amer. J. 63, 362-368.

Cerdà, A., Doerr, S.H., 2005. Influence of vegetation recovery on soil hydrology and erodibility following fire: an 11-year investigation. Int. J. Wildland Fire 14, 423-437.

Cerdà, A., Doerr, S.H., 2008. The effect of ash and needle cover on surface runoff and erosion in the immediate post-fire period. Catena 74, 256-263. 
Cerdà, A., Robichaud, P.R., 2009. Fire effects on soil infiltration. In: Cerdà, A., Robichaud, P.R. (Eds.), Fire Effects on Soils and Restoration Strategies. Science Publishers, Enfield, New Hampshire, USA, pp.81-103.

Certini, G., 2005. Effects of fire on properties of forest soils: a review. Oecologia 143, 1-10.

Czachor, H., Doerr, S.H., Lichner, L., 2010. Water retention of repellent and subcritical repellent soils: New insights from model and experimental investigations. J. Hydrol. 380, 104-111.

DeBano, L.F., 1981. Water repellent soils: a state-of-the-art, General Technical Report, PSW-46. U.S. Department of Agriculture, Forest Service, Pacific Southwest Forest and Range Experiment Station, Berkley, California, USA, 21pp.

DeBano, L.F., Neary, D.G., Ffolliott, P.F., 1998. Fire's Effects on Ecosystems. John Wiley \& Sons, New York, USA.

de Jonge, L.W., Jacobsen, O.H., Moldrup, P., 1999. Soil water repellency: effects of water content, temperature, and particle size. Soil Science Society of America Journal 63, 437-442.

Dekker, L.W., Ritsema, C.J., 1994. How water moves in a water repellent sandy soil. I. Potential and actual water repellency. Water Resources Res. 30, 2507-2517.

Dekker, L.W., Ritsema, C.J., 1995. Finger like wetting patterns in two water-repellent loam soils. J. Environ. Quality 24, 324-333.

Dekker, L.W., Ritsema, C.J., 1996. Variation in water content and wetting patterns in Dutch water repellent peaty clay and clayey peat soils. Catena 28, 89-105.

Dekker, L.W., Doerr, S.H., Oostindie, K., Ziogas, A.K., Ritsema, C.J., 2001. Water repellency and critical water content in a dune sand. Soil Science Soc. of Amer. J. 65, 1667-1674.

Dethier, M.N., Graham, E.S., Cohen, S., Tear, L.M., 1993. Visual versus random-point percent cover estimations: “objective” is not always better. Marine Ecol. Progress Series 96, 93-100. 
Doerr, S.H., Shakesby, R.A., Walsh, R.P.D., 2000. Soil water repellency: its causes, characteristics and hydro-geomorphological significance. Earth-Science Reviews 15, 33-65.

Doerr, S.H., Moody J., 2004. Hydrological effects of soil water repellency: on spatial and temporal uncertainties. Hydrol. Processes 18, 829-832.

Doerr, S.H., Shakesby, R.A., Blake, W.H., Chafer, C.J., Humphreys, G.S., Wallbrink, P.J., 2006a. Effects of differing wildfire severities on soil wettability and implications for hydrological response. J. Hydrology 319, 295-311.

Doerr, S.H., Shakesby, R.A., Dekker, L.W., Ritsema, C.J., 2006b. Occurrence, prediction and hydrological effects of water repellency amongst major soil and land-use types in humid temperate climate. European J. Soil Science 57, 741-754.

Doerr, S.H., Shakesby, R.A., MacDonald, L.H. 2009a. Soil water repellency: A key factor in post-fire erosion. In: Cerdà, A., Robichaud, P.R. (Eds.), Fire Effects on Soils and Restoration Strategies. Science Publishers, Enfield, New Hampshire, USA, pp. 197-223.

Doerr, S.H., Woods, S.W., Martin, D.A., Casimiro, M., 2009b. 'Natural background’ soil water repellency in conifer forests of the north-western USA: Its prediction and relationship to wildfire occurrence. J. Hydrol. 371, 12-21.

Ebel, B.A., Moody, J.A., Martin, D.A., 2012. Hydrologic conditions controlling runoff generation immediately after wildfire. Water Resources Res. 48, WO3529, 1-13.

Elzinga, C.L., Salzer, D.W., Willoghby, J.W., 1998. Measuring and monitoring plant populations. USDI-BLM Technical Reference 1730-1. U.S. Department of Interior, Bureau of Land Management, Denver, Colorado, USA, 492 pp. $<$ http://www.blm.gov/nstc/library/pdf/MeasAndMon.pdf> (date accessed: June 2015) 
Faulkner, H., 1990. Vegetation cover density variations and infiltration patterns on piped alkali sodic soils: implications for the modeling of overland flow in semi-arid areas. In: Thornes, J.B. (ed.), Vegetation and Erosion: Process and Environments. John Wiley and Sons, Chichester, UK, pp. 317-346.

Ferreira, A.J.D., Coelho, C.O.A., Boulet, A.K., Lopes, F.P. 2005. Temporal patterns of solute loss following wildfires in Central Portugal. Int. J. Wildland Fire 14, 401-412.

Feng, G.L., Letey, J., Wu, L., 2001. Water ponding depths affect temporal infiltration rates in a water repellent sand. Soil Science Soc. Amer. 65, 315-320.

Fox, D.M., Darboux, F., Carrega, P., 2007. Effects of fire-induced water repellency on soil aggregate stability, splash erosion, and saturated hydraulic conductivity for different size fractions. Hydrol. Processes 21, 2377-2384.

Gee, G.W., Bauder, J.W., 1986. Particle-size analysis. In: Klute, A. (ed.), Methods of Soil Analysis: Part 1, American Society of Agronomy, Madison, Wisconsin, USA, pp. 383-411.

Huang, C., Gascuel-Odoux, C., Cros-Cayot, S., 2001. Hillslope topographic and hydrologic effects on overland flow and erosion. Catena 46, 177-188.

Huffman, E.L., MacDonald, L.H., Stednick, J.D., 2001. Strength and persistence of fire-induced soil hydrophobicity under ponderosa and lodgepole pine, Colorado Front Range. Hydrol. Processes 15, 2877-2892.

Imeson, A.C., Verstraten, J.M., Van Mulligen, E.J., Sevink, J., 1992. The effects of fire and water repellency on infiltration and runoff under Mediterranean type forests. Catena 19, 345-361. Inbar, A., Lado, M., Sternberg, M., Tenau, H., Ben-Hur, M., 2014. Forest fire effects on soil chemical and physicochemical properties, infiltration, runoff, and erosion in a semiarid Mediterranean region. Geoderma 221-222, 131-038. 
Jiménez, C.C., Tejedor, M., Morillas, G., Neris, J., 2006. Infiltration rates in andisols: effect of changes in vegetation cover (Tenerife, Spain). J. Soil and Water Conservation 61, 153-158.

Johansen, M.P., Hakonson, T.E., Breshears, D.D., 2001. Post-fire runoff and erosion from rainfall simulation: contrasting forests with shrublands and grasslands. Hydrol. Processes 15, 29532965.

Jordán, A., Zavala, L.M., Nava, A.L., Alanís, N., 2009. Occurrence and hydrological effects of water repellency in different soil and land use types in Mexican volcanic highlands. Catena 79, 60-71.

Jordán, A., Zavala, L.M., Mataix-Solera, J., Doerr, S.H. 2013. Soil water repellency: Origin, assessment and geomorphological consequences. Catena 108, 1-5.

Kawamoto, K., Moldrup, P., Komatsu, T., de Jonge, L.W., Oda, M., 2007. Water repellency of aggregate size fractions of volcanic ash soil. Soil Science Soc. Amer. J. 71(6), 1658-1666.

Larsen, I.J., MacDonald, L.H., Brown, E., Rough, D., Welsh, M.J., Pietraszek, J.H., Libohova, Z., Benavides-Solorio, J.D., Schaffrath, K., 2009. Causes of post-fire runoff and erosion: water repellency, surface cover, or soil sealing? Soil Science Soc. Amer. J. 73 (4), 13931407.

Leighton-Boyce, G., Doerr, S.H., Shakesby, R.A., Walsh, R.P.D., 2007. Quantifying the impact of soil water repellency on overland flow generation and erosion: a new approach using rainfall simulation and wetting agent on in situ soil. Hydrol. Processes 21, 2337-2345.

Letey, J., 2001. Causes and consequences of fire-induced soil water repellency. Hydrol. Processes 15, 2867-2875.

Littell, R.C., Milliken, G.A., Stroup, W.W., Wolfinger, R.D., Schabenberger, O., 2006. SAS ${ }^{\circledR}$ for Mixed Models, Second Edition. SAS Institute Inc., Cary, North Carolina, USA. 
Liu, H., Lei, T.W., Zhao, J., Yuan, C.P., Fan, Y.T., Qu, L.Q., 2011. Effects of rainfall intensity and antecedent soil water content on soil infiltrability under rainfall conditions using the run offon-out method. J. Hydrology 396, 24-32.

Lowdermilk, W.C., 1930. Influence of forest litter on run-off, percolation, and erosion. J. Forestry 28, 474-491.

Lozano, E., Jiménez-Pinilla, P., Mataix-Solera, J., Arcenegui, V., Bárcenas, G.M., GonzálezPérez, J.A., García-Orenes, F., Torres, M.P., Mataix-Beneyto, J. 2013. Biological and chemical factors controlling the patchy distribution of soil water repellency among plant species in a Mediterranean semiarid forest. Geoderma 207-208, 212-220.

MacDonald, L.H., Huffman, E.L., 2004. Post-fire soil water repellency: persistence and soil moisture thresholds. Soil Science Soc. Amer. J. 68, 1729-1734.

Martínez-Zavala, L., Jordán-López, A., 2009. Influence of different plant species on water repellency in Mediterranean heathland soils. Catena 76, 215-223.

Mataix-Solera, J., Arcenegui, V., Guerrero, C., Mayoral, A.M., Morales, J., González, J., GarcíaOrenes, F., Gómez, I., 2007. Water repellency under different plant species in a calcareous forest soil in a semiarid Mediterranean environment. Hydrol. Processes 21, 2300-2309.

Mataix-Solera, J., Cerdà, A., Arcenegui, V., Jordán, A., Zavala, L.M., 2011. Fire effects on soil aggregation: A review. Earth-Science Reviews 109, 44-60.

Mataix-Solera, J., Arcenegui, V., Tessler, N., Zornoza, R., Wittenberg, L., Martínez, C., Caselles, P., Pérez-Bejarano, A., Malkinson, D., Jordán, M.M., 2013. Soil properties as key factors controlling water repellency in fire-affected areas: evidences from burned sites in Spain and Israel. Catena 108, 6-13. 
McBride, K., 2000. Soil description of the Bitterroot National Forest. Unpublished report. Available at US Department of Agriculture, Forest Service, Bitterroot National Forest, Hamilton, Montana, USA.

Meeuwig, R.O., 1971. Infiltration and water repellency in granitic soils. Research Paper INT-111. U.S. Department of Agriculture, Forest Service, Intermountain Research Station, Ogden, Utah, USA.

Meyer, L.D., Harmon, W.C. 1979. Multiple-intensity rainfall simulator for erosion research on row sideslopes. Trans. Amer. Soc. Agric. Eng. 22,100-103.

Moral García, F.J., Dekker, L.W., Oostindie, K., Ritsema, C.J., 2005. Water repellency under natural conditions in sandy soils of southern Spain. Australian J. Soil Research 43, 291-296.

Moody, J.A., Shakesby, R.A., Robichaud, P.R., Cannon, S.H., Martin, D.A., 2013. Current research issues related to post-wildfire runoff and erosion processes. Earth-Science Reviews $122,10-37$.

(NRCS), U.S. Department of Agriculture, Natural Resources Conservation Service, 2007. Historical accumulated precipitation (daily) for Site 433 in the state of Montana. <http://www.wcc.nrcs.usda.gov/snotel/snotelday2.pl? site=433\&station=13c39s\&state=mt\&report=precip_accum_hist $>$ (date accessed: June 2015).

Neris, J., Tejedor, M., Rodríguez, M., Fuentes, J., Jiménez, C., 2013. Effect of forest floor characteristics on water repellency, infiltration, runoff and soil loss in Andisols of Tenerife (Canary Islands, Spain). Catena 108, 50-57. 
Nyman, P., Sheridan, G., Lane, N.J., 2010. Synergistic effects of water repellency and macropore flow on the hydraulic conductivity of a burned forest soil, south-east Australia. Hydrol. Processes 24, 2871-2887.

Ott, R.L., Longnecker, M., 2001. An Introduction to Statistical Methods and Data Analysis, fifth edition. Duxbury, Pacific Grove, California, USA.

Parsons, A., Robichaud, P.R., Lewis, S.A., Napper, C., Clark, J.T., 2010. Field guide for mapping post-fire soil burn severity. General Technical Report, RMRS-GTR-243. U.S. Department of Agriculture, Forest Service, Rocky Mountain Research Station, Fort Collins, Colorado, USA, 49 pp.

Peterson, A.E., Bubenzer, G.D., 1986. Intake rate: sprinkler infiltrometer. In: Klute, A., (ed.), Methods of Soil Analysis, Part I. Physical and Mineralogical Methods-Agronomy Monograph no.9 ( $2^{\text {nd }}$ Edition). American Society of Agronomy—Soil Science Society of America, Madison, Wisconsin, USA. pp. 845-870.

Pierson, F.B., Robichaud, P.R., Spaeth, K.E., 2001. Spatial and temporal effects of wildfire on the hydrology of a steep rangeland watershed. Hydrol. Processes 15, 2905-2916.

Prosser, I.P., Williams, L., 1998. The effect of wildfire on runoff and erosion in native Eucalyptus forest. Hydrol. Processes 12, 251-265.

Regalado, C.M., Ritter, A., 2005. Characterizing water dependent soil repellency with minimal parameter requirement. Soil Science Soc. Amer. J. 69, 1955-1966.

Ritsema, C.J., Dekker, L.W., 1994. How water moves in a water repellent sandy soil. Part 2 Dynamics of fingered flow. Water Resources Res. 30, 2519-2531.

Ritsema, C.J., Dekker, L.W., 2000. Preferential flow in water repellent sandy soils: principles and modeling implications. J. Hydrology 231-232, 308-319. 
Robichaud, P.R. 1996. Spatially-varied erosion potential from harvested hillslopes after prescribed fire in the Interior Northwest. PhD Diss. University of Idaho, Moscow ID, 219 pp.

Robichaud, P.R., 2000. Fire effects on infiltration rates after prescribed fire in Northern Rocky Mountain forests, USA. J. Hydrology 231-232, 220-229.

Robichaud, P.R., Hungerford, R.D., 2000. Water repellency by laboratory burning of four northern Rocky Mountain forest soils. J. Hydrology 231-232, 207-219.

Robichaud, P.R., Lewis, S.A., Ashmun, L.E., 2008. New procedure for sampling infiltration to assess post-fire soil water repellency. Research Note, RMRS-RN-33. U.S. Department of Agriculture, Forest Service, Rocky Mountain Research Station, Fort Collins, Colorado, USA.

Robichaud, P.R., Jordan, P., Lewis, S.A., Ashmun, L.E., Covert, S.A., Brown, R.E., 2013 a. Evaluating the effectiveness of wood shred and agricultural straw mulches as a treatment to reduce post-wildfire hillslope erosion in southern British Columbia, Canada. Geomorphology 197, 21-33.

Robichaud, P.R., Lewis, S.A., Wagenbrenner, J.W., Ashmun, L.E., Brown, R.E., 2013b. Post-fire mulching for runoff and erosion mitigation Part I: effectiveness at reducing hillslope erosion rates. Catena 105, 75-82.

Rodriguez-Alleres, M., Benito, E., deBlas, E., 2007. Extent and persistence of water repellency in north-western Spanish soils. Hydrol. Processes 21, 2291-2299.

Rulli, C.M., Bozzi, S., Spada, M., Bocchiola, D., Rosso, R., 2006. Rainfall simulations on a fire disturbed Mediterranean area. J. Hydrology 327, 323-338.

SAS Institute, 2012. SAS 9.4 for Windows. SAS Institute, Cary, North Carolina, USA. 
Shakesby, R.A., Doerr, S.H., Walsh, R.P.D., 2000. The erosional impact of soil hydrophobicity: current problems and future research directions. J. Hydrology 231-232, 178-191.

Shakesby, R.A., Doerr, S.H., 2006. Wildfire as a hydrological and geomorphological agent. Earth-Science Reviews 74, 269-307.

Shoji, S., Nanzyo, M., Dahlgren, R.A., 1993. Volcanic Ash Soils: genesis, properties, and utilization. Elsevier Publishing, Amsterdam.

Stoof, C.R., Vervoort, R.W., Iwema, J., van den Elsen, E., Ferreira, A.J.D., Ritsema, C.J., 2012. Hydrological response of a small catchment burned by experimental fire. Hydrology and Earth System Sciences 16, 267-285.

Tessler, N., Wittenberg, L., Greenbaum, N., 2013. Soil water repellency persistence after recurrent forest fires on Mount Carmel, Israel. Int. J. Wildland Fire 22, 515-526.

USDA Forest Service, 2000. Burned Area Emergency Rehabilitation (BAER) Report; 2500-8 Valley Complex Fires-Phase I. Unpublished report. Available from U.S. Department of Agriculture, Forest Service, Bitterroot National Forest, Hamilton, Montana, USA.

Vierira, D.C.S, Fernández, C., Vega, J.A., Keizer, J.J. 2015. Does soil burn severity affect the post-fire runoff and interrill erosion response? A review based on meta-analysis of field rainfall simulation data. J. Hydrology 523, 452-464.

Vogelmann, E.S., Reichert, J.M., Prevedello, J., Consensa, C.O.B., Oliveira, A.É., Awe, G.O., Mataix-Solera, J., 2013. Threshold water content beyond which hydrophobic soils become hydrophilic: The role of soil texture and organic matter content. Geoderma 209-210, 177187.

Wang, Z., Wu, Q.J., Wu, L., Ritsema, C.J., Dekker, L.W., Feyen, J., 2000. Effects of soil water repellency on infiltration rate and flow instability. J. Hydrology 231-232, 265-276. 
823 Wilcox, B.P., Wood, M.K., Tromble, J.M., 1988. Factors influencing infiltrability of semiarid 824 mountain slopes. J. Range Manage. 41, 197-206.

825 Woods, S.W., Balfour, V.N., 2008. The effect of ash on runoff and erosion after a severe forest 826 wildfire, Montana, USA. Int. J. Wildland Fire 17, 535-548.

827 Woods, S.W., Balfour, V.N., 2010. The effects of soil texture and ash thickness on the post-fire 828 hydrological response from ash-covered soils. J. Hydrology 393, 274-286.

829 Zehe, E., Elsenbeer, H., Lindenmaier, F., Schulz, K., Blöschl, G., 2007. Patterns of predictability $830 \quad$ in hydrological threshold systems. Water Resources Res. 43(7), W07434.

831

832 


\section{Table 1}

Location, simulated rainfall rate, rainfall amount, runoff ratios and sediment yields in unburned and burned plots, and reference for rainfall simulator studies in severely burned coniferous forests. Plot areas were between 0.24 and $33 \mathrm{~m}^{2}$. If multiple events were conducted on the same plot, only the first simulation is shown here to represent dry antecedent conditions. All data are averages from the year of the fire.

\begin{tabular}{|c|c|c|c|c|c|c|c|}
\hline Location & $\begin{array}{l}\text { Rainfall } \\
\text { rate } \\
\left(\mathrm{mm} \mathrm{h}^{-1}\right)\end{array}$ & $\begin{array}{l}\text { Rainfall } \\
\text { amount } \\
(\mathrm{mm})\end{array}$ & $\begin{array}{l}\text { Unburned } \\
\text { runoff } \\
\text { ratio } \\
(\%)\end{array}$ & $\begin{array}{l}\text { Unburned } \\
\text { sediment } \\
\text { yield } \\
\left(\mathrm{g} \mathrm{m}^{-2}\right)\end{array}$ & $\begin{array}{l}\text { Burned } \\
\text { runoff } \\
\text { ratio } \\
(\%)\end{array}$ & $\begin{array}{l}\text { Burned } \\
\text { sediment } \\
\text { yield } \\
\left(\mathrm{g} \mathrm{m}^{-2}\right)\end{array}$ & Reference \\
\hline $\begin{array}{l}\text { Western } \\
\text { Montana }\end{array}$ & 100 & 100 & 55 & 14 & 69 & 1757 & This study \\
\hline $\begin{array}{l}\text { Western } \\
\text { Montana }\end{array}$ & 76 & 76 & $\begin{array}{l}\text { Not } \\
\text { reported }\end{array}$ & $\begin{array}{l}\text { Not } \\
\text { reported }\end{array}$ & 44 & 1040 & $\begin{array}{l}\text { Woods and } \\
\text { Balfour, } \\
2008\end{array}$ \\
\hline $\begin{array}{l}\text { Western } \\
\text { Montana }\end{array}$ & 94 & 47 & 8.5 & 4 & 26 & 262 & $\begin{array}{l}\text { Robichaud, } \\
1996,2000\end{array}$ \\
\hline $\begin{array}{l}\text { Central } \\
\text { Idaho }\end{array}$ & 94 & 47 & 32 & 85 & 55 & 628 & $\begin{array}{l}\text { Robichaud, } \\
1996,2000\end{array}$ \\
\hline $\begin{array}{l}\text { Southern } \\
\text { British } \\
\text { Columbia }\end{array}$ & 80 & 27 & $\begin{array}{l}\text { Not } \\
\text { reported }\end{array}$ & $\begin{array}{l}\text { Not } \\
\text { reported }\end{array}$ & 46 & 600 & $\begin{array}{l}\text { Robichaud } \\
\text { et al., 2013a }\end{array}$ \\
\hline $\begin{array}{l}\text { Central } \\
\text { Colorado }\end{array}$ & $\begin{array}{l}78 \text { (86 in } \\
\text { burned } \\
\text { areas) }\end{array}$ & $78(86)$ & 55 & 34 & 66 & 428 & $\begin{array}{l}\text { Benavides- } \\
\text { Solorio and } \\
\text { MacDonald, } \\
2001\end{array}$ \\
\hline $\begin{array}{l}\text { Northern } \\
\text { New } \\
\text { Mexico }^{\mathrm{a}}\end{array}$ & 60 & 60 & 20 & 21 & 42 & 414 & $\begin{array}{l}\text { Johansen et } \\
\text { al., } 2001\end{array}$ \\
\hline $\begin{array}{l}\text { Eastern } \\
\text { Spain }\end{array}$ & 55 & 55 & $\begin{array}{l}\text { Not } \\
\text { reported }\end{array}$ & $\begin{array}{l}\text { Not } \\
\text { reported }\end{array}$ & 43 & $76 \mathrm{~g}$ & $\begin{array}{l}\text { Cerdà and } \\
\text { Doerr, } 2008\end{array}$ \\
\hline $\begin{array}{l}\text { NW } \\
\text { Italy }^{b}\end{array}$ & 74 & 74 & $\begin{array}{l}\text { Not } \\
\text { reported }\end{array}$ & $\begin{array}{l}\text { Not } \\
\text { reported }\end{array}$ & 29 & 17 & $\begin{array}{l}\text { Rulli et al., } \\
2006\end{array}$ \\
\hline $\begin{array}{l}\text { Central } \\
\text { Portugal }\end{array}$ & 51 & $38-51^{c}$ & 5.5 & $\begin{array}{l}\text { Not } \\
\text { reported }\end{array}$ & 65 & $\begin{array}{l}\text { Not } \\
\text { reported }\end{array}$ & $\begin{array}{l}\text { Ferreira et } \\
\text { al., } 2005\end{array}$ \\
\hline
\end{tabular}

${ }^{\text {a }}$ Rotating boom simulator, $32.5 \mathrm{~m}^{2}$ plots.

${ }^{\mathrm{b}}$ Simulation area $13 \mathrm{~m}^{2}$.

${ }^{c}$ Estimated from intensity and range of durations 


\section{Table 2}

Number of plots, soil moisture, understory canopy cover, ground cover, mean soil water repellency occurrence at $0-3 \mathrm{~cm}$ depth, total infiltration, runoff, and collected sediment by year and treatment. The standard error of the means are shown in parentheses. Different letters within a column indicate significant differences at $\alpha=0.05$.

\begin{tabular}{|c|c|c|c|c|c|c|c|c|c|}
\hline Year & $\begin{array}{l}\text { Treat- } \\
\text { ment }\end{array}$ & $\mathrm{n}$ & $\begin{array}{l}\text { Soil } \\
\text { moisture } \\
(\%)\end{array}$ & $\begin{array}{l}\text { Canopy } \\
\text { cover } \\
(\%) \\
\end{array}$ & $\begin{array}{l}\text { Ground } \\
\text { cover }^{*} \\
(\%)\end{array}$ & $\begin{array}{l}\text { Water } \\
\text { repellency } \\
\text { occurrence } \\
(\%)\end{array}$ & $\begin{array}{l}\text { Infiltration } \\
(\mathrm{mm})\end{array}$ & $\begin{array}{l}\text { Runoff } \\
(\mathrm{mm})\end{array}$ & $\begin{array}{l}\text { Sediment } \\
\text { yield } \\
\left(\mathrm{g} \mathrm{m}^{-2}\right)\end{array}$ \\
\hline \multirow[t]{3}{*}{ PF0 } & Control & 21 & $18(2.0) \mathrm{de}$ & $25(3.7) \mathrm{cd}$ & $87(2.1) \mathrm{a}$ & $93(3.9) \mathrm{a}$ & $44(3.5) b c$ & $58(3.5) \mathrm{bcd}$ & $50(7.1) \mathrm{c}$ \\
\hline & Bare & 21 & $18(2.4) \mathrm{de}$ & $0(0)$ & $0(0)$ & 99 (0.6) abcd & $19(2.6) \mathrm{e}$ & $86(3.0) \mathrm{a}$ & 849 (77) a \\
\hline & Burned & 60 & $17(2.0) \mathrm{cd}$ & $0.1(0.04) \mathrm{f}$ & $10(1.0) \mathrm{b}$ & $88(2.3) \mathrm{ab}$ & $31(1.0) \mathrm{de}$ & $70(1.1) b$ & 1757 (114) a \\
\hline \multirow[t]{3}{*}{ PF1 } & Control & 21 & 33 (2.5) abc & $28(4.1) \mathrm{cd}$ & $90(1.8) \mathrm{a}$ & $39(8.6) \mathrm{d}$ & $45(4.0) \mathrm{bc}$ & $56(3.9) \mathrm{cd}$ & $15(3.0) \mathrm{d}$ \\
\hline & Bare & 21 & $36(4.2) \mathrm{ab}$ & $0(0)$ & $0(0)$ & $38(7.1) \mathrm{d}$ & $36(2.7) \mathrm{bcd}$ & 64 (2.7) bcd & $677(60) \mathrm{a}$ \\
\hline & Burned & 59 & $15(1.1) \mathrm{d}$ & $7(1.2) \mathrm{e}$ & $6(1.4) c$ & 79 (3.5) abc & $38(1.4) b c$ & $61(1.4) \mathrm{cd}$ & $1099(60) \mathrm{a}$ \\
\hline \multirow[t]{3}{*}{ PF2 } & Control & 21 & $44(4.8) \mathrm{a}$ & $42(5.6) a b c$ & $91(2.3) \mathrm{a}$ & $51(8.8) \mathrm{cd}$ & $48(3.6) b$ & $53(3.6) \mathrm{d}$ & $7(1.4) \mathrm{e}$ \\
\hline & Bare & 20 & $44(5.7) \mathrm{a}$ & $0(0)$ & $0(0)$ & $62(9.0) \mathrm{bcd}$ & $34(3.2) \mathrm{cd}$ & $67(3.2) b c$ & $624(81) \mathrm{a}$ \\
\hline & Burned & 59 & $17(1.4) \mathrm{cd}$ & 33 (3.1) bd & $17(3.9) \mathrm{b}$ & $48(4.4) \mathrm{d}$ & $37(1.3) b c$ & $62(1.3) \mathrm{cd}$ & $391(47) b$ \\
\hline \multirow[t]{3}{*}{ PF5 } & Control & 20 & 24 (4.2) bcd & $59(8.9) \mathrm{ab}$ & $91(1.3) \mathrm{a}$ & $94(4.1) \mathrm{a}$ & $47(3.4) b$ & $53(3.4) \mathrm{d}$ & $54(22) \mathrm{cd}$ \\
\hline & Bare & 17 & $15(2.3)$ cde & $0(0)$ & $0(0)$ & $99(1.0) \mathrm{ab}$ & 41 (1.7) bcd & 59 (1.7) bcd & 1277 (158) a \\
\hline & Burned & 46 & $3(0.4) \mathrm{e}$ & $45(2.5) \mathrm{ac}$ & $42(5.2) \mathrm{a}$ & $45(5.2) \mathrm{d}$ & $84(1.5) \mathrm{a}$ & $14(1.5) \mathrm{e}$ & $15(3.6) \mathrm{de}$ \\
\hline
\end{tabular}

Bare plots were not included in the statistical analyses of these variables as all canopy and ground cover was removed before simulations began. 


\section{Table 3}

Mean soil moisture, water repellency occurrence at $0-3 \mathrm{~cm}$ depth, infiltration, runoff, and sediment yield for a subset of 14 plots sampled in spring PF1. Standard errors of the means are shown in parentheses. Data for the same 14 plots are included for PF0 and PF1 for comparison.

\begin{tabular}{llllllll}
\hline Year & Treatment & $\mathrm{n}$ & $\begin{array}{l}\text { Soil } \\
\text { moisture } \\
(\%)\end{array}$ & $\begin{array}{l}\text { Water } \\
\text { repellency } \\
\text { occurrence } \\
(\%)\end{array}$ & $\begin{array}{l}\text { Infiltration } \\
(\mathrm{mm})\end{array}$ & $\begin{array}{l}\text { Runoff } \\
(\mathrm{mm})\end{array}$ & $\begin{array}{l}\text { Sediment yield } \\
\left(\mathrm{g} \mathrm{m}^{-2}\right)\end{array}$ \\
\hline PF0 & Control & 3 & $26(12)$ & $100(0)$ & $47(13)$ & $56(14)$ & $60(24)$ \\
& Bare & 3 & $29(13)$ & $100(0)$ & $22(12)$ & $83(12)$ & $626(132)$ \\
& Burned & 8 & $12(2.1)$ & $92(4.7)$ & $29(1.8)$ & $70(1.6)$ & $2117(308)$ \\
Spring & Control & 3 & $74(14)$ & $4.2(4.2)$ & $67(12)$ & $31(12)$ & $9.2(3.9)$ \\
PF1 & Bare & 3 & $52(8.1)$ & $21(21)$ & $45(8.2)$ & $53(8.3)$ & $738(293)$ \\
& Burned & 8 & $21(3.7)$ & $36(14)$ & $46(2.7)$ & $52(2.8)$ & $1278(128)$ \\
PF1 & Control & 3 & $26(3.5)$ & $13(13)$ & $40(11)$ & $62(9.6)$ & $5.1(0.8)$ \\
& Bare & 3 & $49(22)$ & $33(8.3)$ & $35(0.2)$ & $66(0.8)$ & $811(371)$ \\
& Burned & 8 & $16(2.4)$ & $69(14)$ & $36(1.5)$ & $63(1.8)$ & $1195(68)$ \\
\hline
\end{tabular}


Figure Captions for Robichaud et al.

Fig. 1. Location of study sites, Daly Creek snow telemetry site, and the burned area along the Montana-Idaho border. Site map on right is depicted by rectangle in locator map.

Fig. 2. PF5 rainfall simulation on a bare plot in an unburned site. The surface vegetation, litter, and duff were removed from the plot and the area immediately adjacent to the plot. (Photo credit: USDA-Forest Service J. Yost)

Fig. 3. Particle size distribution of burned and unburned surface soils.

Fig. 4. Mean occurrence (\%) of soil water repellency by year, treatment, and depth. Mean soil moisture (\%) by year and treatment is listed.

Fig. 5. Mean infiltration rate $\left(\mathrm{mm} \mathrm{h}^{-1}\right)$ plotted over the $60 \mathrm{~min}$ rainfall simulation for each treatment and year.

Fig. 6. Results of the excavation showing mean percentage of the trench cut face $(50 \mathrm{~cm}$ wide and $20 \mathrm{~cm}$ deep in $2 \mathrm{~cm}$ depth increments) wetted by the simulated rainfall. Data shown by year and by treatment. Dark and light shading indicate depth segments, and both represent wet soil. $\mathrm{T}$ Inf $=$ Total Infiltration $(\mathrm{mm}) . \mathrm{T}$ WA $=$ Total Wetted Area $(\%)$.

Fig. 7. Mean sediment concentration $\left(\mathrm{g} \mathrm{L}^{-1}\right)$ over the 60 min rainfall simulation for each treatment and year.

Fig. 8. Mean soil water repellency occurrence plotted against soil moisture by treatment (colors) and year (symbols) including Spring PF1. 
Figure 1
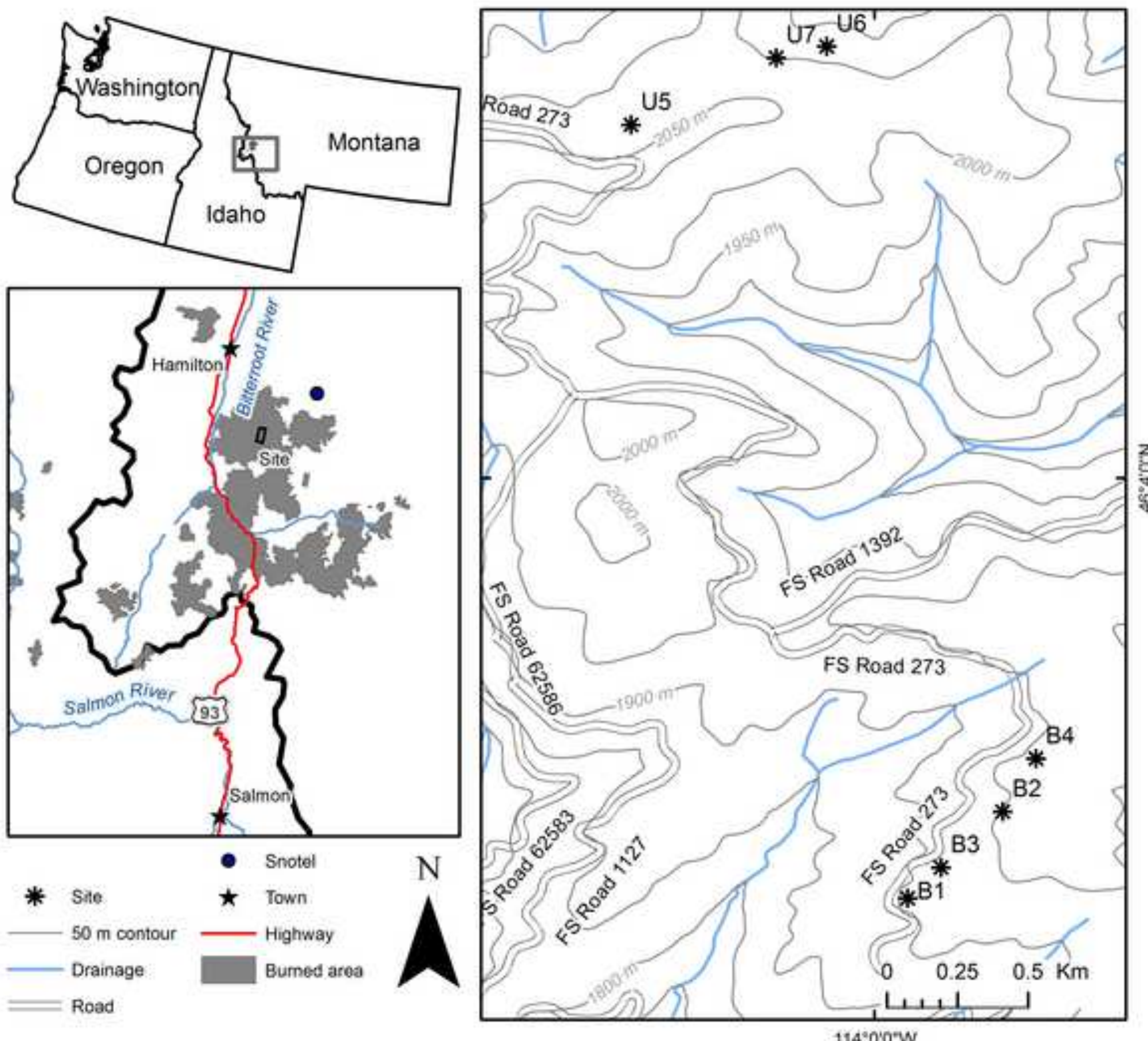

$z$
8
0
0
8 


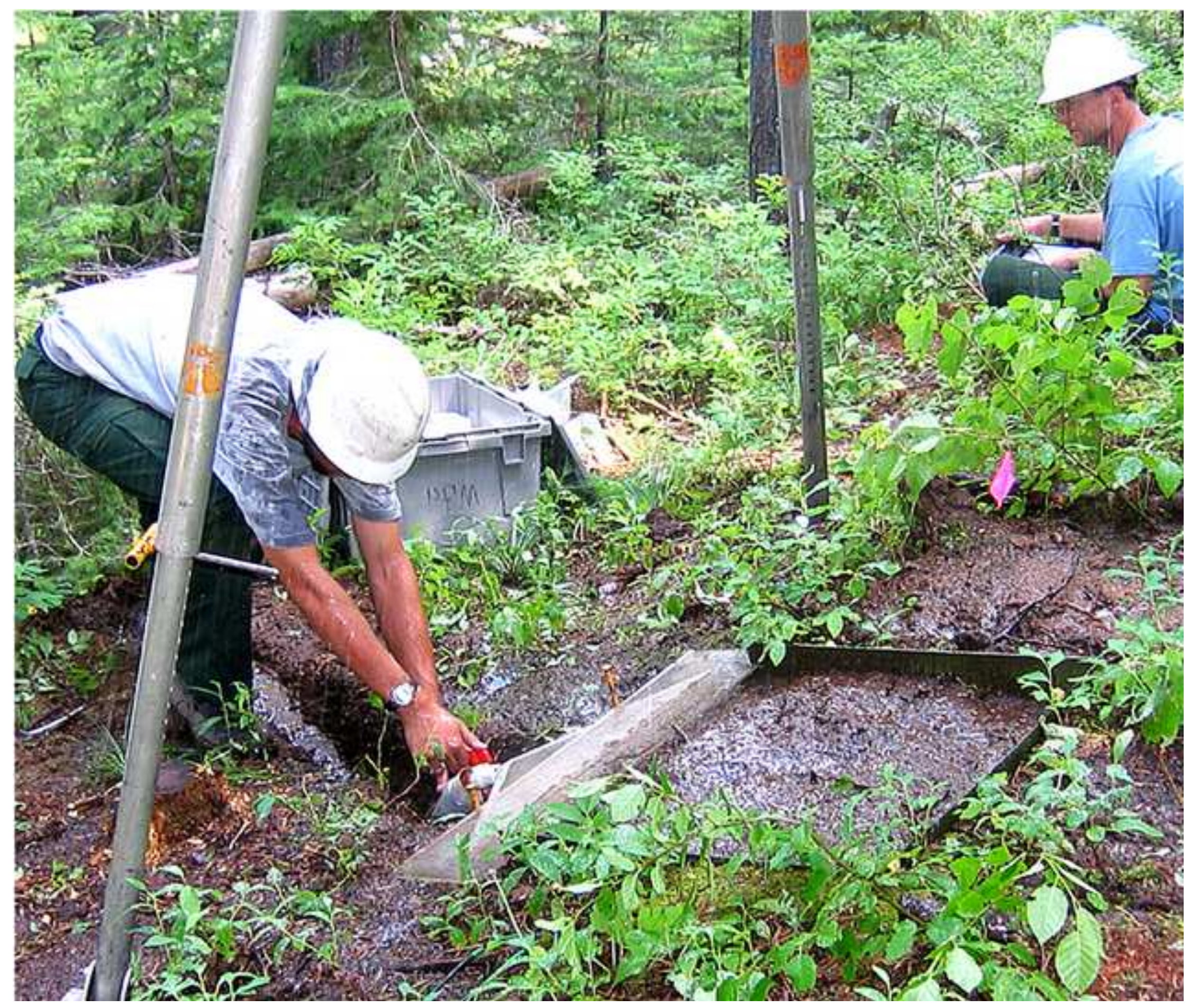




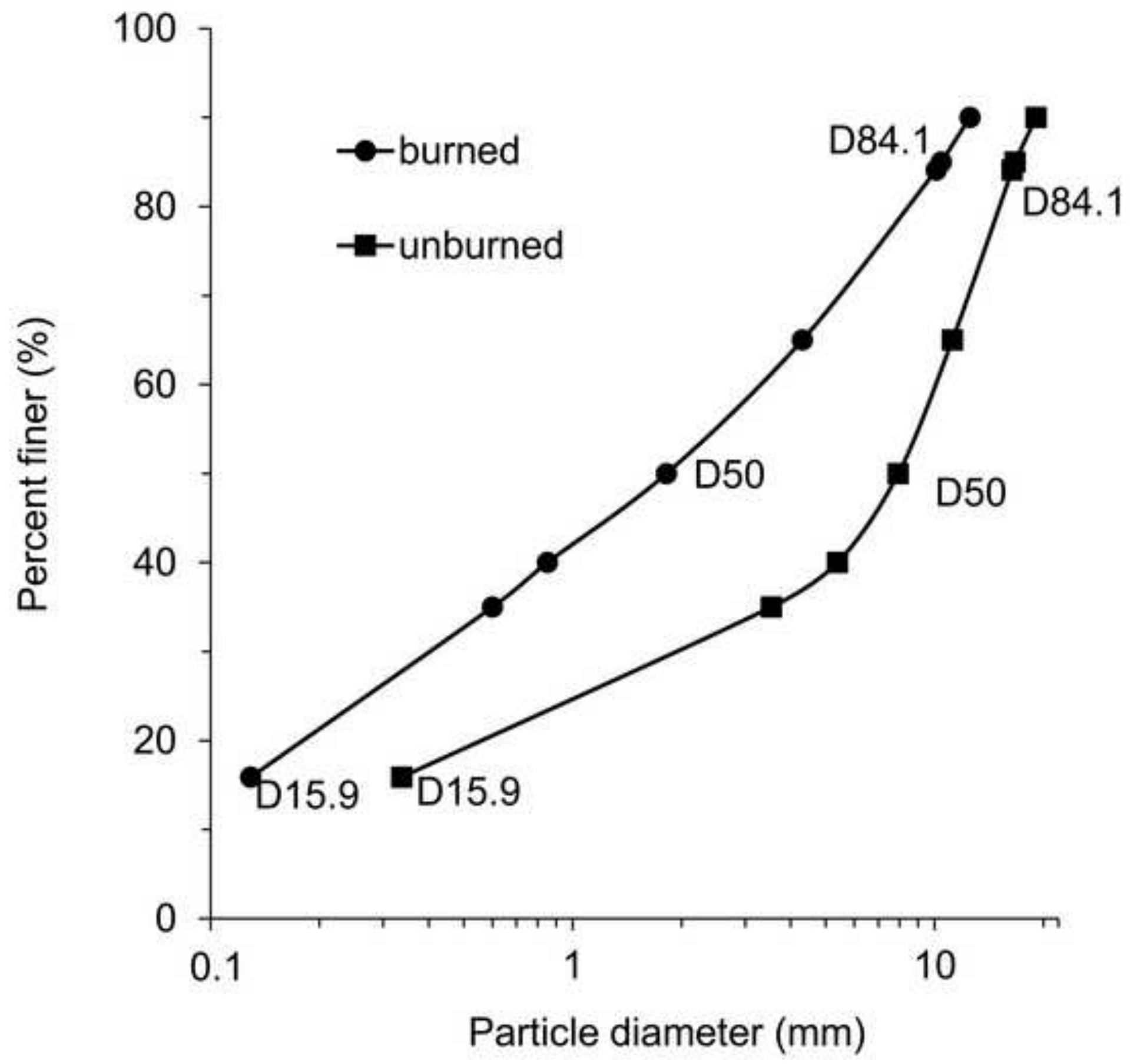



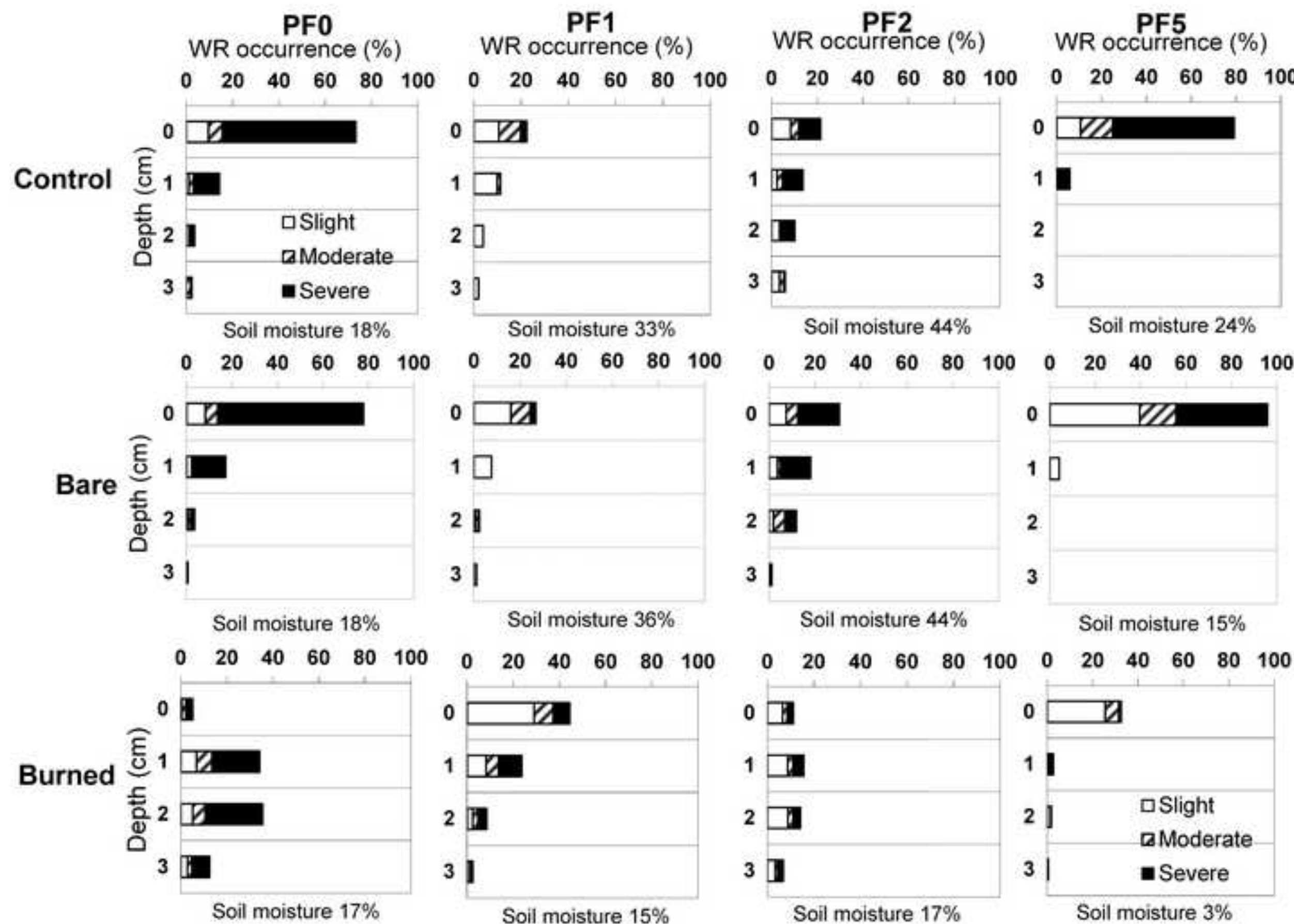

$\begin{array}{lllll}40 & 60 & 80 & 100\end{array}$

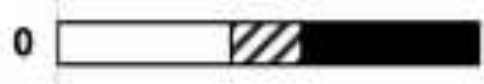

10

2.

3

$\begin{array}{llllll}0 & 20 & 40 & 60 & 80 & 100\end{array}$

$\begin{array}{llllll}0 & 20 & 40 & 60 & 80 & 100\end{array}$

Soil moisture $15 \%$
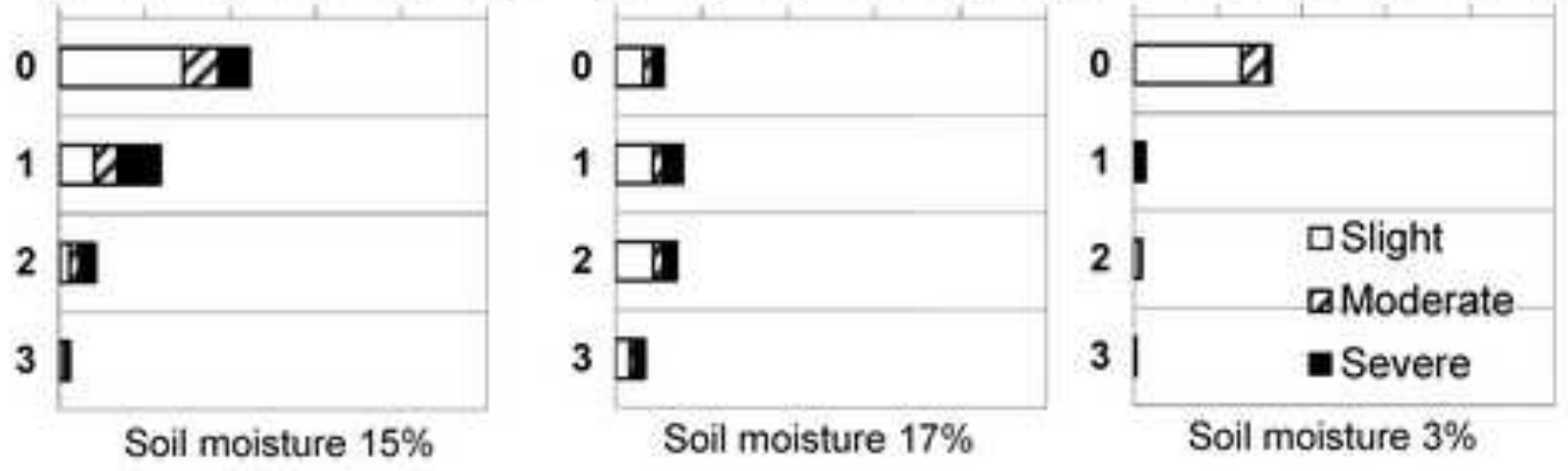


\section{Control}

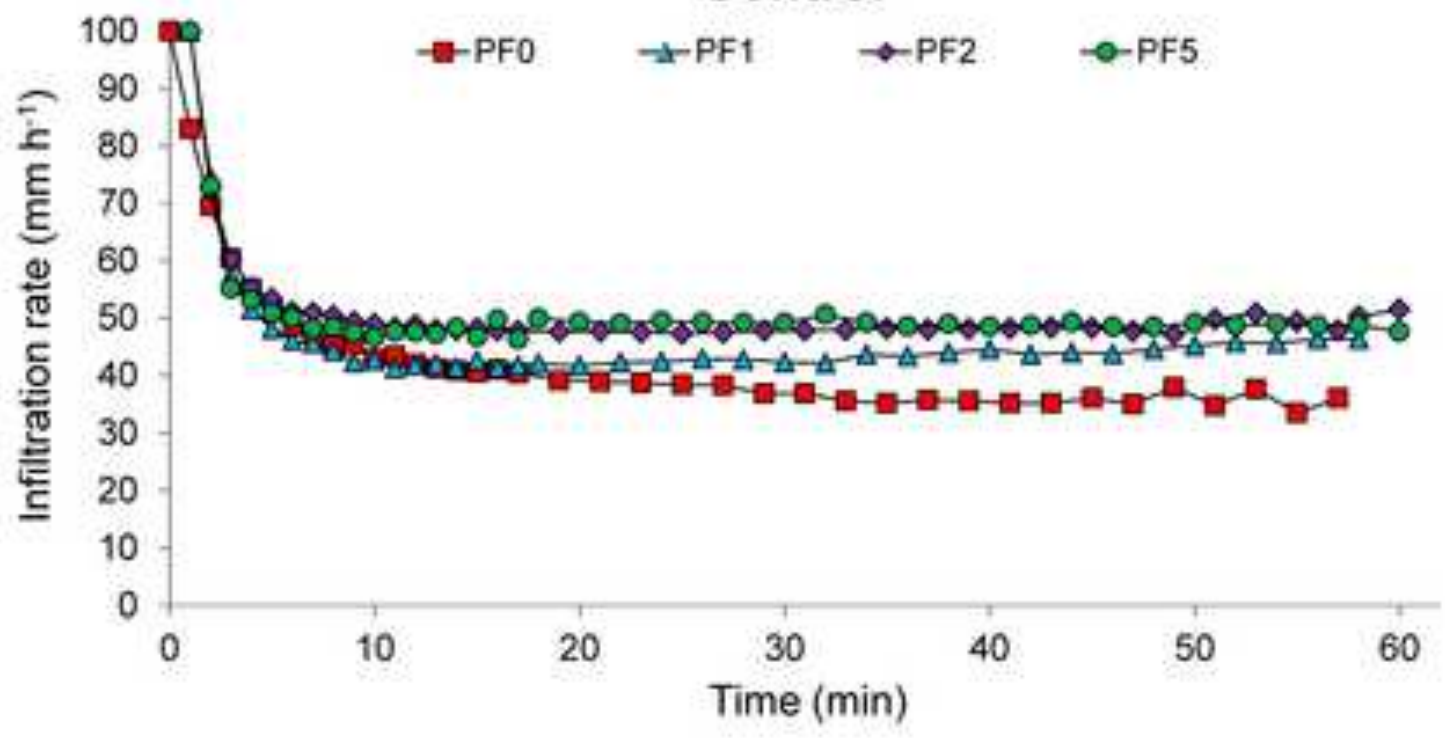

\section{Bare}

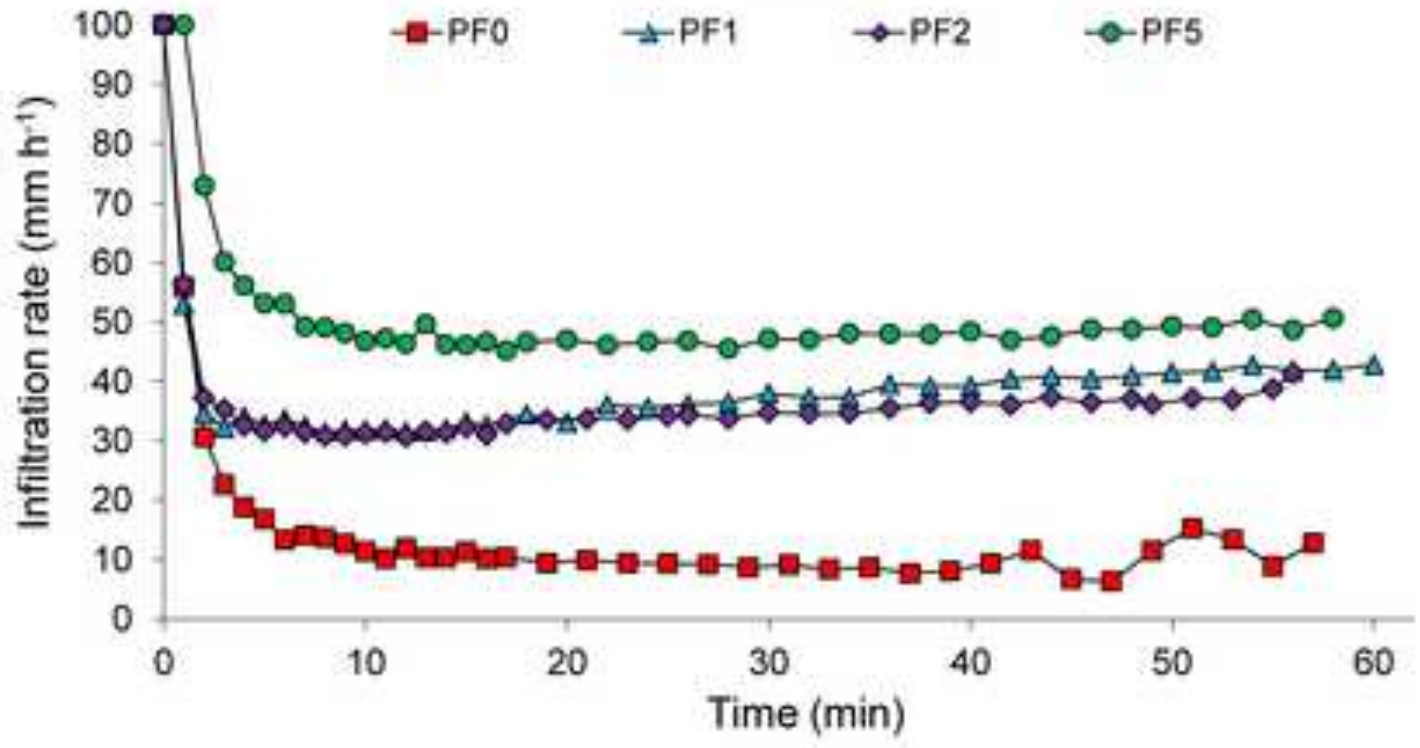

\section{Burned}

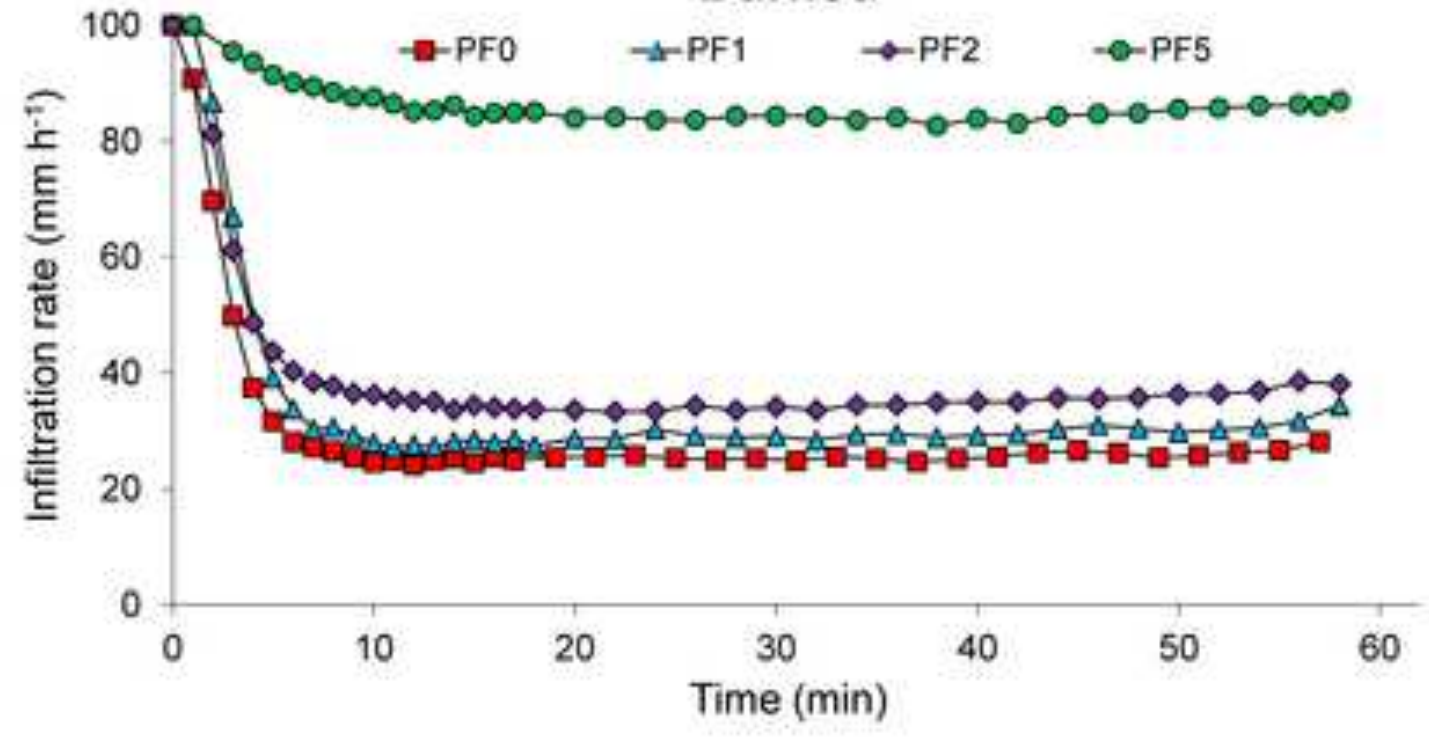


PFO

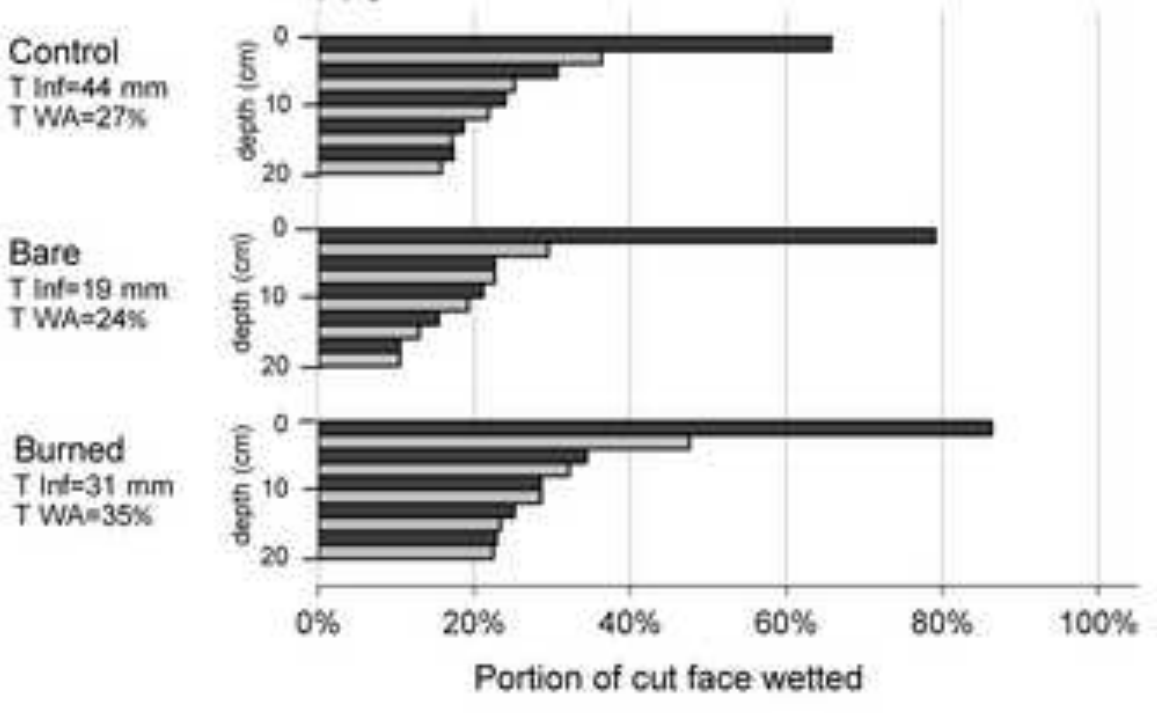

PF2

Control:

T Inf $=48 \mathrm{~mm}$

TWA $W 6 \%$

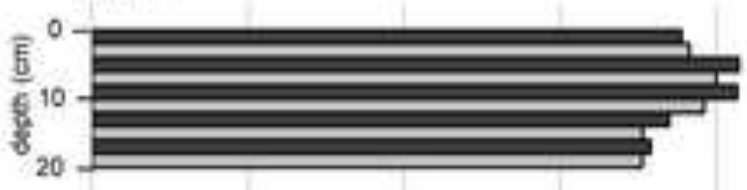

Bare

$T$ Inf=34 mum

TWA $75 \%$

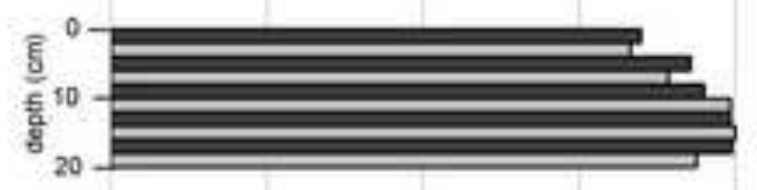

Burned

T inf $37 \mathrm{~mm}$

$T W A=72 \%$

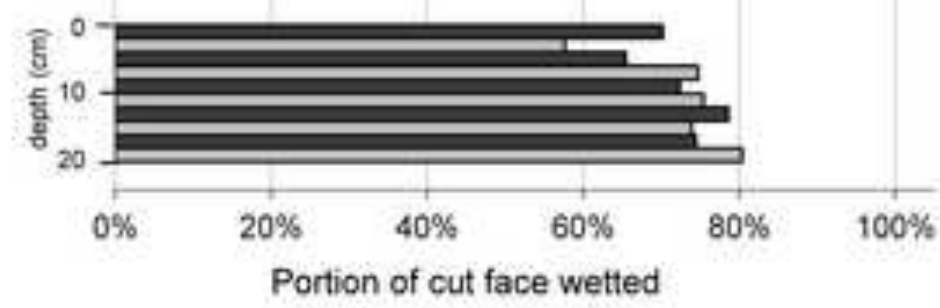

PF1

Control

T inf $=45 \mathrm{~mm}$

TWA $=91 \%$

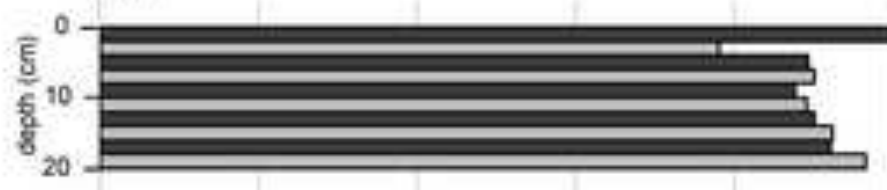

Bare

I inf $=36 \mathrm{~mm}$

$T W A=86 \%$

Burned

I Inf=38 mm

$T$ WA $89 \%$
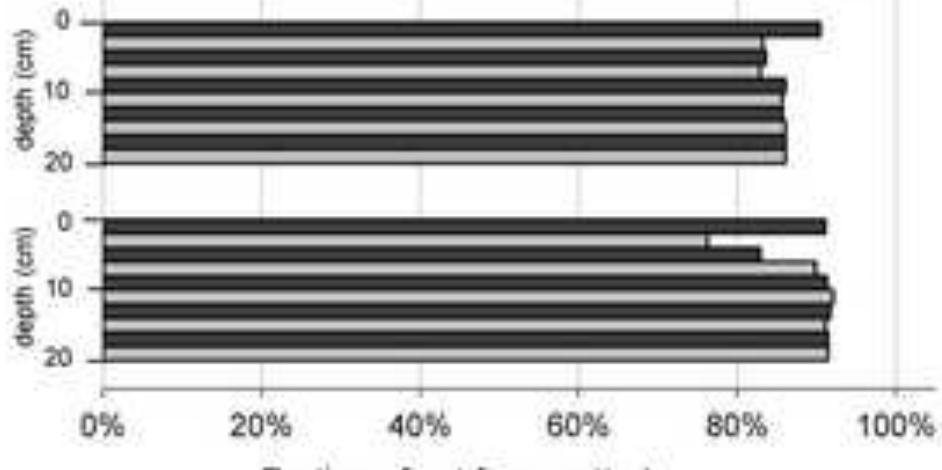

PF5

Control

T Int $=47 \mathrm{~mm}$

$T$ WA=35\%

Bare

Tint $=41 \mathrm{~mm}$

TWA $W 45 \%$
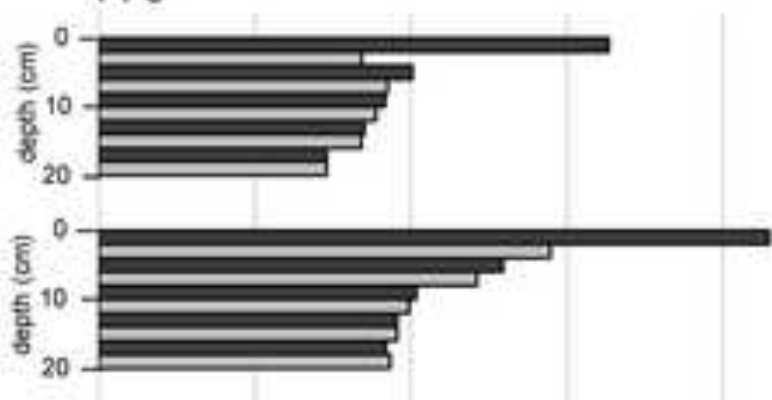

Burned

T inf $=84 \mathrm{~mm}$

$T$ WA $=86 \%$

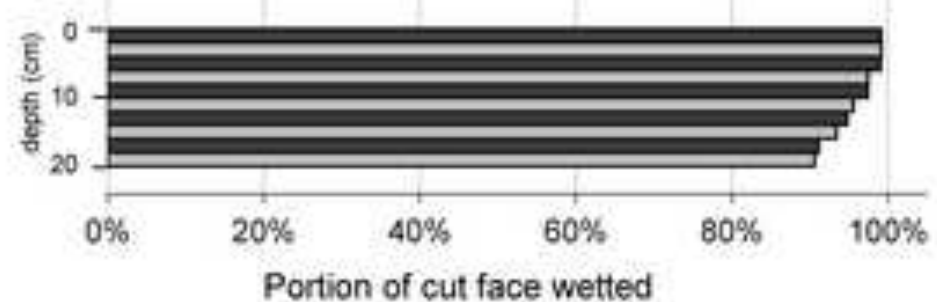


Control

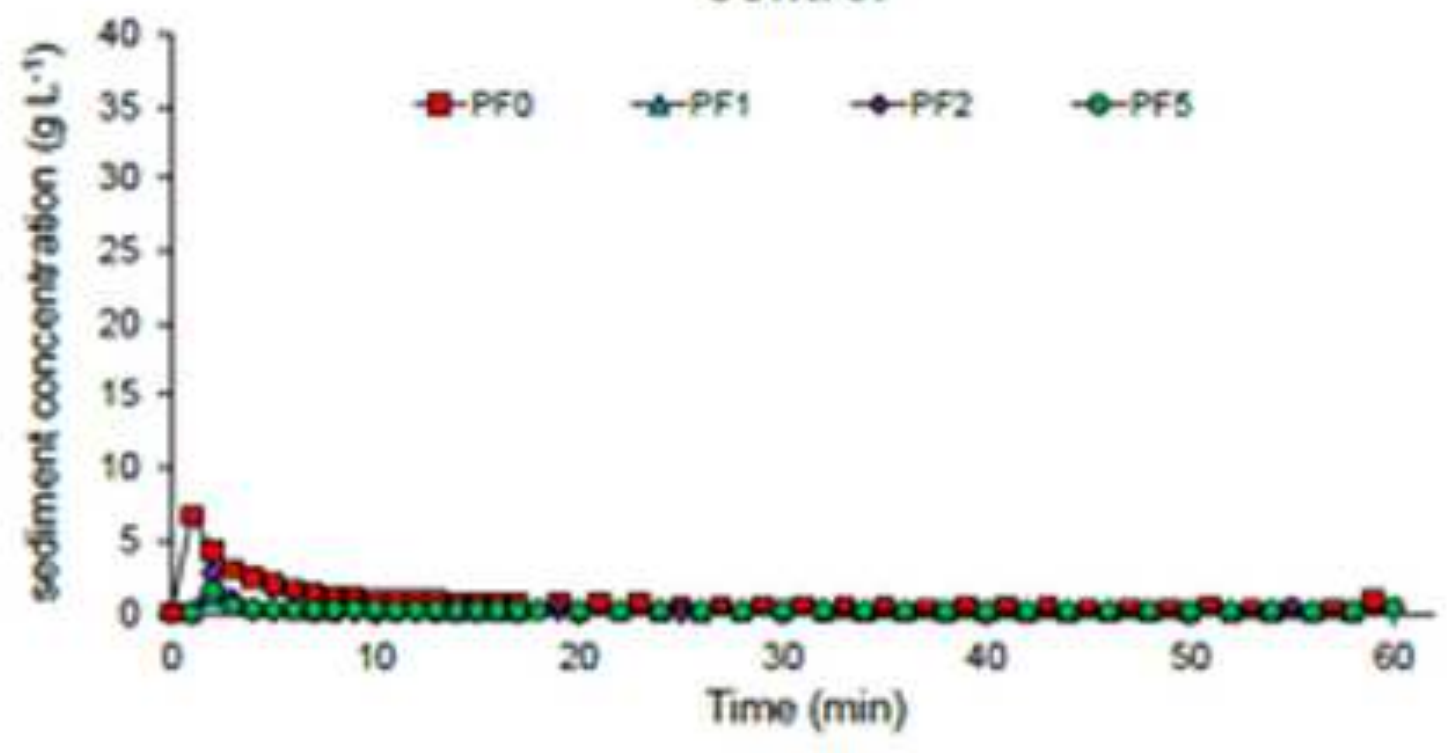

Bare
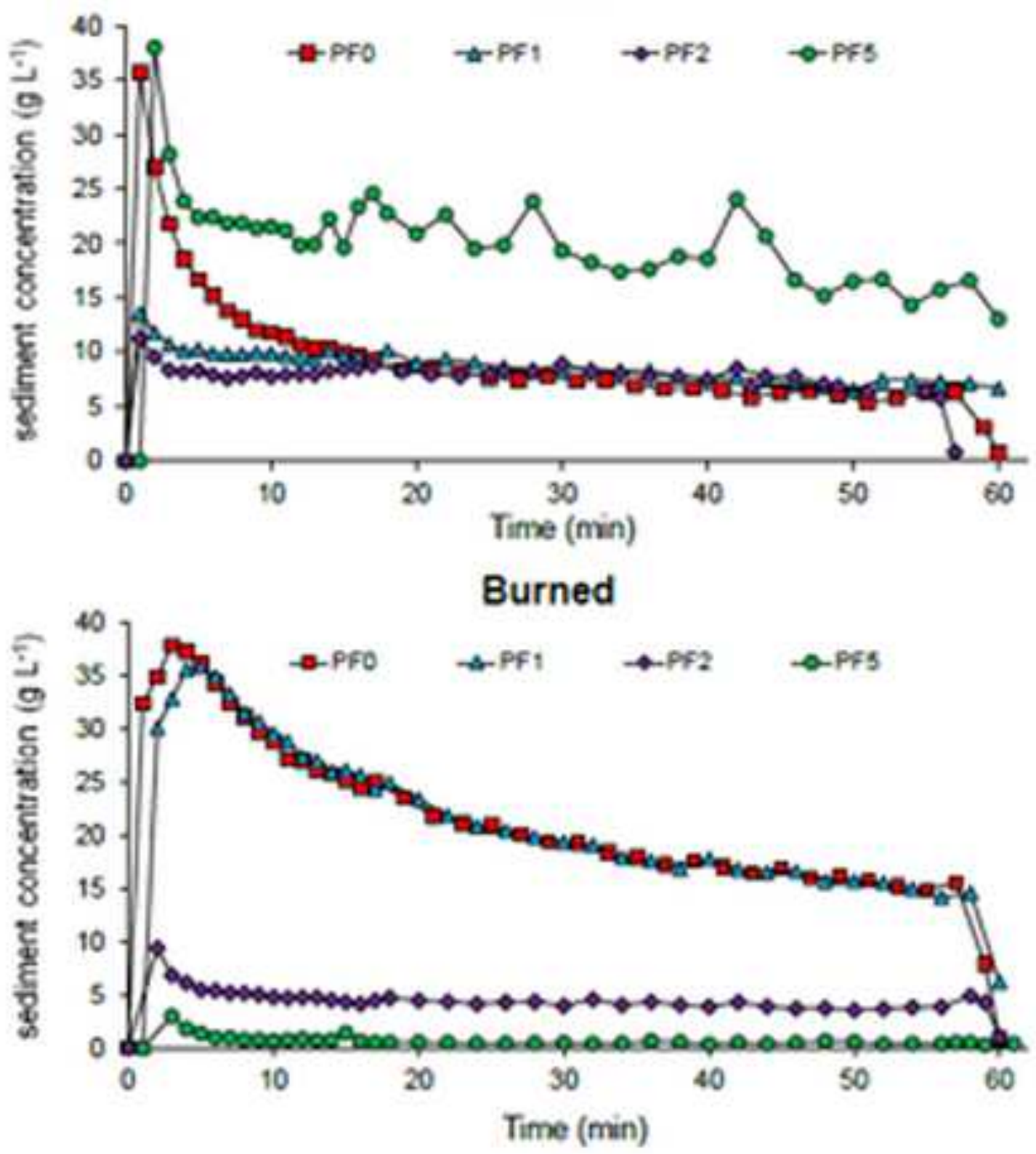


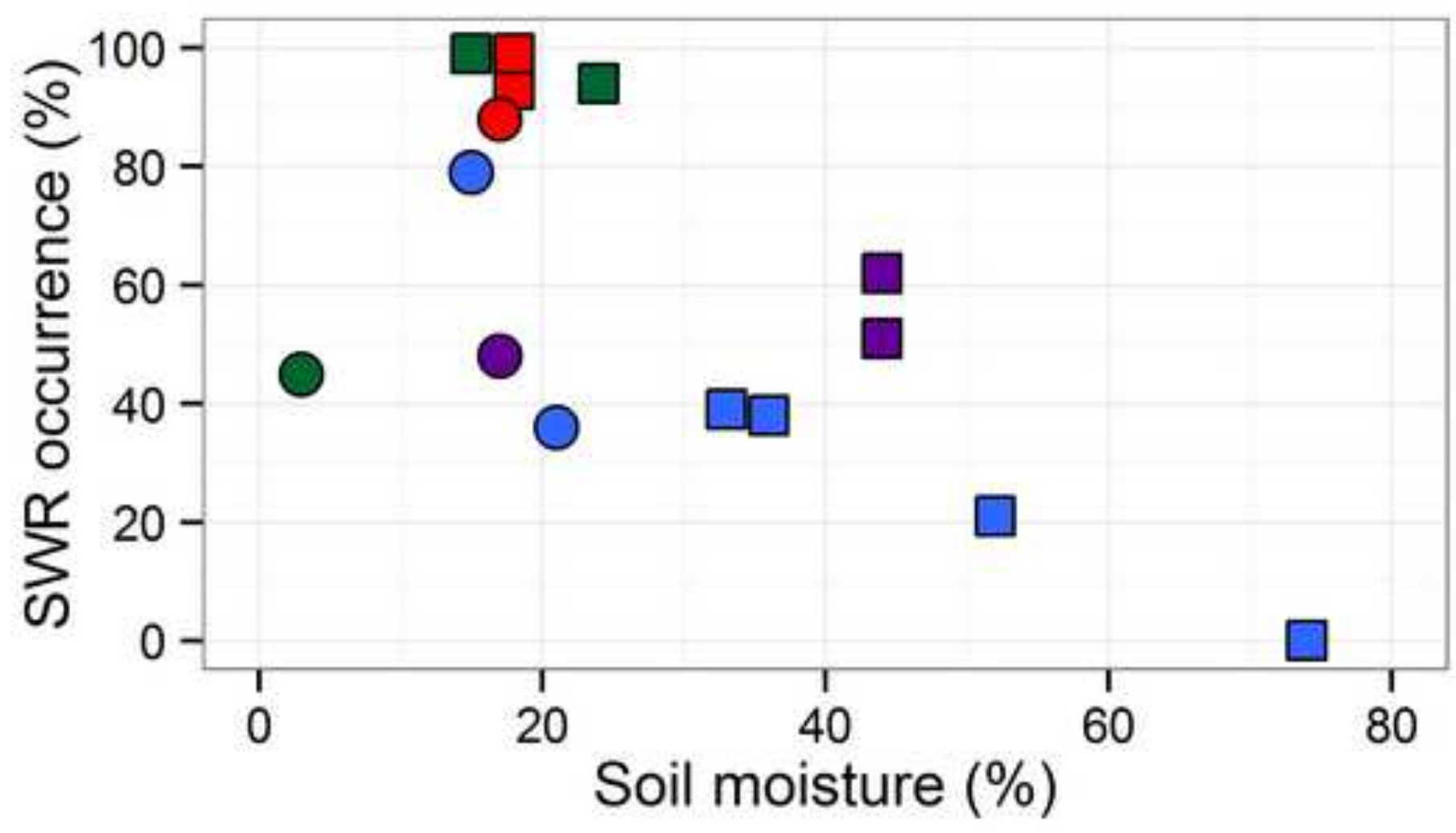

Treatment

$\bigcirc$ Burned

$\square$ Unburned

Year

- PFO

PF1

- PF2

P PF5

Soil moisture (\%) 